\title{
Ecospeak in Transnational Environmental Tort Proceedings
}

Jeff Todd ${ }^{*}$

\section{INTRODUCTION}

In March 2014, Judge Lewis Kaplan issued an injunction forbidding U.S. enforcement of a nearly $\$ 9$ billion Ecuadoran judgment against Chevron that was procured by the plaintiffs' attorneys' fraud. ${ }^{1}$ The injunction is the latest in a legal saga related to alleged environmental torts arising from petroleum production in the Lago Agrio region of Ecuador; the litigation has spanned three decades and numerous countries and thus has attracted considerable scholarly attention. Commentators have addressed the initial lawsuit that was filed in the United States under the Alien Tort Statute but dismissed on forum non conveniens (FNC) grounds, Aguinda v. Texaco, Inc., and cases consolidated with it; ${ }^{2}$ the subsequent proceedings in Ecuador pursuant to legislation secured by the plaintiffs' attorneys and the potential obstacles for having that judgment recognized and enforced; ${ }^{3}$ the actual preemptive

\footnotetext{
*Assistant Professor of Business Law, Department of Finance \& Economics, Texas State University. J.D. (University of Texas School of Law); Ph.D. (Texas A\&M University); M.A., B.A. (University of South Alabama). The author would like to thank his research assistant Jaci Kahn and the editorial staff of the University of Kansas Law Review. The author was an associate at Gibson, Dunn \& Crutcher LLP, the firm that represents Chevron in the U.S. litigation discussed in this Article; the views expressed herein are entirely those of the author, and nobody from Gibson Dunn or Chevron had any input into the article.

1. Chevron Corp. v. Donziger, 974 F. Supp. 2d 362 (S.D.N.Y. 2014) (Judge Lewis Kaplan issued an extensive 500 page opinion).

2. E.g., Judith Kimerling, Indigenous Peoples and the Oil Frontier in Amazonia: The Case of Ecuador, ChevronTexaco, and Aguinda v. Texaco, 38 N.Y.U. J. INT'L L. \& POL. 413 (2006); Malcolm J. Rogge, Towards Transnational Corporate Accountability in the Global Economy: Challenging the Doctrine of Forum Non Conveniens in In re: Union Carbide, Alfaro, Sequihua, and Aguinda, 36 TEX. InT'L L.J. 299 (2001); Jeffrey A. Van Detta, Justice Restored: Using a Preservation-of-Court-Access Approach to Replace Forum Non Conveniens in Five International Product-Injury Case Studies, 24 Nw. J. INT'L L. \& Bus. 53 (2003); see also Aguinda v. Texaco, Inc., 142 F. Supp. 2d 534 (S.D.N.Y. 2001), aff'd, 303 F.3d 470 (2d Cir. 2002); Jota v. Texaco, Inc., 157 F.3d 153 (2d Cir. 1998).

3. E.g., John S. Baker, Jr. \& Agustin Parise, Conflicts in International Tort Litigation Between U.S. and Latin American Courts, 42 U. MiAmi InTER-AM. L. ReV. 1 (2010); M. Ryan Casey \& Barrett Ristroph, Boomerang Litigation: How Convenient is Forum Non Conveniens in Transnational Litigation?, 4 BYU INT'L L. \& MGMT. REV. 21 (2007); Lucien J. Dhooge, Aguinda v.
} 
action brought by Chevron in the United States to enjoin enforcement; ${ }^{4}$ and the parallel arbitration between Chevron and the Republic of Ecuador pursuant to a Bilateral Investment Treaty (BIT). ${ }^{5}$

Although the duration and number of proceedings, the sums involved, and the massive fraud are extraordinary, the Lago Agrio proceedings provide a vehicle to understand an issue that arises in less spectacular cases (like a Colombian widow's wrongful death action for her husband's fall in an elevator, or the claims of Costa Rican commercial farmers for property damage related to the fungicide Benlate) $)^{6}$ : the lack of access by plaintiffs from developing countries to an adequate forum for their tort claims against U.S. multinational

ChevronTexaco: Discretionary Grounds for the Non-Recognition of Foreign Judgments for Environmental Injury in the United States, 28 VA. ENVTL. L.J. 241 (2010) [hereinafter Discretionary]; Lucien J. Dhooge, Aguinda v. ChevronTexaco: Mandatory Grounds for the NonRecognition of Foreign judgments for Environmental Injury in the United States, 19 J. TRANSNAT'L L. \& POL'Y 1 (2009) [hereinafter Mandatory]; Jonathan C. Drimmer \& Sarah R. Lamoree, Think Globally, Sue Locally: Trends and Out-of-Court Tactics in Transnational Tort Actions, 29 BERKELEY J. INT'L L. 456 (2011); Cassandra Burke Robertson, Transnational Litigation and Institutional Choice, 51 B.C. L. REV. 1081 (2010); Cortelyou Kenney, Comment, Disaster in the Amazon: Dodging "Boomerang Suits" in Transnational Human Rights Litigation, 97 CAL. L. REV. 857 (2009); Christina Weston, Comment, The Enforcement Loophole: Judgment-Recognition Defenses as a Loophole to Corporate Accountability for Conduct Abroad, 25 EMORY INT'L L. REV. 731 (2011)

4. E.g., Suraj Patel, Delayed Justice: A Case Study of Texaco and the Republic of Ecuador's Operations, Harms, and Possible Redress in the Ecuadorian Amazon, 26 Tul. EnVTL. L.J. 71 (2012); Catherine A. Rogers, When Bad Guys Are Wearing White Hats, 1 StAn. J. CompleX Litig. 487 (2013); Jeff Todd, The Rhetoric of Recognition, 45 MCGEORGE L. REV. 209 (2013) [hereinafter Rhetoric of Recognition]; Christopher A. Whytock \& Cassandra Burke Robertson, Forum Non Conveniens and the Enforcement of Foreign Judgments, 111 COLUM. L. REV. 1444 (2011).

5. E.g., Charles N. Brower \& Diane Brown, From Pinochet in the House of Lords to the Chevron/Ecuador Lago Agrio Dispute: The Hottest Topics in International Dispute Resolution, 26 Pac. McGeorge Global Bus. \& Dev. L.J. 1 (2013); George K. Foster, Investors, States, and Stakeholders: Power Asymmetries in International Investment and the Stabilizing Potential of Investment Treaties, 17 LEWIS \& CLARK L. REV. 361 (2013); Chiara Giorgetti, Mass Tort Claims in International Investment Proceedings: What Are the Lessons from the Ecuador-Chevron Dispute?, 34 U. PA. J. INT'L L. 787 (2013); Robert V. Percival, Global Law and the Environment, 86 WASH. L. REV. 579 (2011); see also Bilateral Investment Treaty, U.S.-Ecuador, Aug. 27, 1993, S. TREATY Doc. No. 103-15 (1997) [hereinafter U.S.-Ecuador BIT]; Claimants' Notice of Arbitration, Chevron Corp. v. Republic of Ecuador, No. 2009-23 (Perm. Ct. Arb. Sept. 23, 2009), http://www.chevron. com/Documents/Pdf/Ecuadorbiten.pdf.

6. Van Detta, supra note 2, at 72-86 (citing Iragorri v. United Techs. Corp., 274 F.3d 65 (2d Cir. 2001) (en banc); Proyectos Orchimex de Costa Rica, S.A. v. E.I. duPont de Nemours \& Co., 896 F. Supp. 1197 (M.D. Fla. 1995)). Several scholars have also compared the Lago Agrio litigation to the cases involving agricultural workers from Latin American countries who allege exposure to the pesticide DBCP, which were dismissed from the U.S. on FNC grounds in the 1980s and 1990s; subsequent cases by Nicaraguan plaintiffs have either been dismissed with prejudice from the U.S. or, if they have foreign money judgments, denied recognition and enforcement. E.g., Rhetoric of Recognition, supra note 4, passim; Drimmer \& Lamoree, supra note 3, passim. 
corporations. The judicial systems of plaintiffs' home countries are often inadequate to handle mass tort claims ${ }^{7}$ - and sometimes are even hostile to certain types of plaintiffs like indigenous peoples. ${ }^{8}$ Many commentators therefore advocate a change to FNC or to the hodge-podge of state laws about recognition and enforcement of foreign money judgments. $^{9}$ Another potential solution would blur the lines between private and public international law. While current international tribunals allow for claims only between States, or by citizens against a State but not a corporation, ${ }^{10}$ BITs between the United States and developing countries might be drafted to allow for affected citizens of the host country to have access to U.S. courts - or even to arbitration tribunals that until now have been available only for the Host State and the corporation. ${ }^{11}$

The ultimate goal is a forum that accommodates the needs of all stakeholders, but a closer analysis reveals that none of these solutions can quite do that. For example, changing or eliminating FNC to force a U.S. trial may help plaintiffs, but it does not necessarily force all stakeholders to participate - one noteworthy fact in granting the Aguinda dismissal was the lack of full participation by Ecuador and PetroEcuador, which had sovereign immunity. ${ }^{12}$ And the procedures enacted in plaintiffs' home countries upon which the judgments are based invite

7. E.g., Rhetoric of Recognition, supra note 4, at 236.

8. E.g., Kimerling, supra note 2, at 426-27 (describing how Ecuador sought to assimilate the native inhabitants of the Amazon region into the dominant national culture through tactics that threatened the survival of the people); Rebecca Tsosie, Indigenous Peoples and Global Climate Change: Intercultural Models of Climate Equity, 25 J. ENVTL. L. \& LiTIG. 7, 9-10 (2010) (noting that Latin American nations often give timber and mineral rights that result in the destruction of the native lands of indigenous peoples).

9. E.g., Baker \& Parise, supra note 3, at 30-31 (urging a return to territoriality-based principles of conflicts of laws that would have the United States apply the law of the foreign forum in judicial proceedings); Montre D. Carodine, Political Judging: When Due Process Goes International, 48 WM. \& MARY L. REV. 1159, 1165 (2007) (proposing that the systemic inadequacy ground be eliminated as unconstitutional); Kenney, supra note 3, at 865 (advocating for more aggressive dismissal conditions on defendants at FNC stage); Whytock \& Robertson, supra note 4, at 1500-01 (recommending that judgment debtors be judicially estopped from arguing the systemic inadequacy ground of non-recognition during enforcement actions for cases previously dismissed for FNC).

10. Foster, supra note 5, at 390; Giorgetti, supra note 5, at 794; see Maura Mullen de Bolívar, Note, A Comparison of Protecting the Environmental Interests of Latin-American Indigenous Communities from Transnational Corporations under International Human Rights and Environmental Law, 8 J. TRANSNAT'L L. \& POL'Y 105, 138-42, 147 (1998) (detailing petition brought by indigenous peoples against Ecuador in the Inter-American Commission on Human Rights and how it "will not solve their immediate problems").

11. Foster, supra note 5, at 393, 398; Megan Wells Sheffer, Bilateral Investment Treaties: A Friend or Foe to Human Rights?, 39 DENV. J. INT'L L. \& POL'Y 483, 493-94, 506 (2011).

12. Aguinda v. Texaco, Inc., 303 F.3d 470, 474 (2d Cir. 2002). 
manipulation and fraud, ${ }^{13}$ so a streamlined recognition and enforcement process may not be viable. While turning to public law solutions like treaties offers interesting possibilities, these require the consent of the States involved - and to an extent the acquiescence of the multinational corporations. ${ }^{14}$ An examination of the actions and arguments of the stakeholders during the Lago Agrio proceedings reveals an unwillingness to open more access. Indeed, the parties have framed their interests in narrow ways, continually reducing their complex relationships to "usversus-them" oppositions, with the "us" and the "them" changing to take advantage of the limitations of the particular forum.

Scholars need to understand these oppositional constructs if they are to find solutions to the problem of forums that do not allow for participation by all stakeholders. Audience identity, framing strategies, and explication of texts are rhetorical concerns, so rhetorical theory can provide the avenue for this understanding. ${ }^{15}$ Because the Lago Agrio proceedings deal with environmental torts, environmental rhetoric is particularly apt for this analysis. Though rarely applied in legal scholarship, ${ }^{16}$ environmental rhetoric offers insights about the ways in which language about environmental issues - in particular the ways in which stakeholders define themselves and each other-reinforces entrenched positions and limits the ability of stakeholders to understand each other. ${ }^{17}$ By explicating and understanding these limits, we can look

13. Rogers, supra note 4, at 505; see Jeff Todd, Phantom Torts and Forum Non Conveniens Blocking Statutes: Irony and Metonym in Nicaraguan Special Law 364, 43 U. MiAMI INTER-AM L. Rev. 291, 314-16 (2012) [hereinafter Phantom Torts] (detailing a California court's findings about how a Nicaraguan blocking statute contributed to a fraudulent scheme that tainted pesticide exposure claims).

14. Foster, supra note 5, at 399, 404.

15. Kirsten K. Davis, Legal Forms as Rhetorical Transaction: Competency in the Context of Information and Efficiency, 79 UMKC L. REV. 667, 677 (2011); Jonathan Remy Nash, Framing Effects and Regulatory Choice, 82 NOTRE DAME L. REV. 313 (2006); Rhetoric of Recognition, supra note 4, at 212, 220-21; Gerald Wetlaufer, Rhetoric and Its Denial in Legal Discourse, 76 VA. L. REV. 1545, 1546-48 (1990); see Holly Doremus, The Rhetoric and Reality of Nature Protection: Toward a New Discourse, 57 WASH. \& LEE L. REV. 11, 12 (2000) (writing that "rhetoric has the very real effect of severely constraining our perception of a problem and its potential solutions").

16. Michael Burger, Environmental Law / Environmental Literature, 40 ECOLOGY L.Q. 1, 3 (2013) (claiming that his article is the first to integrate Law and Literature scholarship with the study of environmental law).

17. E.g., Rick Carpenter, Place Identity and the Socio-Spatial Environment, in RouTLEDGE STUDIES IN RHETORIC AND COMMUNICATION: ENVIRONMENTAL RHETORIC AND ECOLOGIES OF PlACE 200 (2013) (Peter N. Goggin ed., 2013) (claiming that stakeholder in environmental debates often align "in terms of a supporter and opponent binary"); Peter N. Goggin, Introduction, in ROUTLEDGE STUDIES IN RHETORIC AND COMMUNICATION: ENVIRONMENTAL RHETORIC AND ECOLOGIES OF PlACE, supra, at 1, 5 ("Environmental rhetorics ... tend to contribute to polarizing public opinion on environmental concerns and engender divisive discourse that Killingsworth and Palmer term 'ecospeak."”) (citing M. JiMmie KillingSWORTH \& JACQUELINE S. PALMER, 
for ways to achieve some level of common understanding, and from there potential solutions. ${ }^{18}$

Section II explains environmental rhetoric, with a focus on the foundational work of Killingsworth and Palmer, Ecospeak, and its grounding in preeminent twentieth century rhetorician Kenneth Burke's concept of identification. ${ }^{19}$ This Section also shows how scholars in both the humanities and law have applied environmental rhetoric. Section III summarizes the facts and proceedings in the Lago Agrio litigation and arbitration. Section IV addresses the legal scholarship about the lack of access by foreign plaintiffs to the courts of their own country or of the United States, potential solutions through revisions of U.S. court access doctrines, and the shortcomings of these proposals in light of the results of the Lago Agrio proceedings. Section V then turns to another solution proffered in several recent articles, the potential for BITs to provide foreign individuals with access to U.S. courts or to international arbitration tribunals. From this background the article in Section VI explicates texts from the Lago Agrio proceedings to demonstrate how stakeholders employ the tactics of ecospeak to reinforce their entrenched positions, thus demonstrating that not only private but also public law solutions may be more elusive than what scholars hope. In Section VI, the Article concludes that a better understanding of the points of shared interests among the stakeholders may nonetheless allow for redress for environmental harms by States and, at least to an extent, for foreign individuals.

ECOSPEAK: RHETORIC AND ENVIRONMENTAL POLITICS IN AMERICA (1992)).

18. E.g., Burger, supra note 16 , at 5 (writing that ecocritical techniques like environmental rhetoric "offer[] a way to uncover how we identify and define problems (and problem-makers), how we conceive desirable goals (and goal-achievers) and how we craft solutions"); Carl G. Herndl \& Stuart C. Brown, Introduction, in GREeN CUlture: ENVIRONMENTAL RHETORIC IN CONTEMPORARY AMERICA 3, 3-5 (Carl G. Herndl \& Stuart C. Brown eds., 1996) ("rhetoric and its analytic methods can help us understand the nature of our environmental debates and their outcomes.").

19. Burke developed his theory of dramatism over eight books and numerous articles. See William H. Rueckert, KenNeth Burke and the Drama of Human Relations xiii (2d ed. 1982). Although none of his individual works captures this technique, several scholars have attempted to synthesize Burke's corpus. See id.; Robert L. Heath, Realism and Relativism: A Perspective on Kenneth Burke (1986); Greig E. Henderson, Kenneth Burke: Literature AND LANGUAGE AS SYMBOLIC ACTION (1988). More modest treatments can also be found in legal literature. E.g., Delia B. Conti, Narrative Theory and the Law: A Rhetorician's Invitation to the Legal Academy, 39 DuQ. L. REv. 457 (2001); Jeff Todd, The Poetics and Ethics of Negligence, 50 CAL. W. L. REV. 75 (2013). 


\section{ENVIRONMENTAL RHETORIC AND ECOSPEAK}

A central tenet of law and rhetoric is that the law is created through its practice, through the discursive acts of the persons involved in the litigation of disputes. ${ }^{20}$ Accordingly, to understand legal issues, critics must examine both the practice of law and its practitioners-broadly defined to include parties, courts, juries, deliberative bodies, and even persons who are not part of legal proceedings. ${ }^{21}$ While the interplay of litigants in an adversarial system is the paradigm for rhetoric as argument, even seemingly neutral tribunals employ rhetorical strategies when they adopt the position of the prevailing party to justify their choice of finding that that litigant is right while the other is wrong. ${ }^{22}$ Davis thus calls rhetorical analysis "an exploration of the meaningmaking process, one in which the law is constituted, as human beings located within particular historical and cultural communities write, read, argue about, and decide legal issues." ${ }^{, 3}$ Rhetorical critics therefore take texts that embody discursive practices and arguments, such as judicial opinions, as the object of study. ${ }^{24}$

In analyzing judicial opinions, the critic must consider not only the discursive moves made by participants, but also how non-participants are obfuscated or avoided. After all, tribunals minimize or even exclude some voices from being heard even though those persons have a stake in

20. Neil MacCormick, Rhetoric and the Rule of LaW: A Theory of Legal Reasoning 6-7 (2005) (writing that the law arises in the context of adjudication and the practice of decisionmaking among rival arguments); Francis J. Mootz, Rhetorical Knowledge in Legal Practice and Theory, 6 S. CAL. INTERDISC. L. J. 491, 584 (1998) (calling "[Justice] the condition which permits the legal actors and authorities to come to know what justice demands in the situation through a process of argumentation. This rhetorical knowledge is made possible by the critical dimensions of legal practice."); Rhetoric of Recognition, supra note 4, at 212 ("Rhetorical theory requires that we approach the law not in the abstract but in the context of practice, as the interplay between litigants and courts and even extending to the social and political context"); James Boyd White, Law as Rhetoric, Rhetoric as Law: The Arts of Cultural and Communal Life, 52 U. CHI. L. REV. 684, 684 (1985) (Rhetoric is "the central art by which community and culture are established, maintained, and transformed.").

21. Mootz, supra note 20, at 575-76; Rhetoric of Recognition, supra note 4, at 216-21; White, supra note 20 , at 692 .

22. MACCORMICK, supra note 20, at 123; see Mootz, supra note 20, at 571 ("Ultimately, judicial consideration of the case and issuance of a written opinion mark a distinct rhetorical practice shaped by the judge's effort first to persuade herself and then to persuade the parties in the litigation and the hypothetical collection of all reasonable lawyers.").

23. Davis, supra note 15, at 677 (citation omitted).

24. Rhetoric of Recognition, supra note 4, at 212; Wetlaufer, supra note 15, at 1546, 1548; White, supra note 20, at 697; see Jeff Todd, A Rhetoric of Warning Defects, 54 S. TEX. L. REv. 343, 347 (2012) ("Rhetoric posits that meaning and power reside in the textual relationship."). 
the outcome of the proceedings. ${ }^{25}$ Rhetorical criticism therefore begins with the questions: "[W]hat voices does the law allow to be heard, what relations does it establish among them? With what voice, or voices, does the law itself speak?"26 Mootz writes that the law is just when the argumentative positions of all stakeholders "are taken up freely in an arena that grants them a fair hearing." 27 Davis urges legal scholars to "do more than trace the precedents that have been left to us by privileged social actors." ${ }^{28}$ Rather than certainty and closure, a rhetorical view of law pulls us in the direction of complexity, contingency, and uncertainty. ${ }^{29}$

A number of legal scholars have applied rhetoric to explore the complexities of environmental issues ranging from arguments for or against the passage of environmental protection laws, to the framing strategies used to portray the different regulatory options for combatting greenhouse gas emissions, to a tropological analysis of the scholarship and proceedings related to FNC blocking statutes. ${ }^{30}$ While applying general rhetorical theory provides a rationale for the practice of law, ${ }^{31}$ environmental rhetoric is particularly apt for critiquing, understanding, and potentially resolving the complex interrelationships of stakeholders in international environmental tort disputes. Killingsworth and Palmer in their foundational book on environmental rhetoric, Ecospeak, write:

Classically defined as the production and interpretation of signs and the use of logical, ethical, and emotional appeals in deliberations about public action, rhetoric is both a theory and a practical art. On the one hand, it analyzes and models discourse practices; on the other hand, it seeks to improve these practices.

\footnotetext{
25. Rhetoric of Recognition, supra note 4 , at 220.

26. White, supra note 20, at 697 .

27. Mootz, supra note 20, at 582-83.

28. Davis, supra note 15 , at 677 (citation omitted).

29. Wetlaufer, supra note 15 , at 1595.

30. Doremus, supra note 15 , at 12 (writing that "rhetoric has the very real effect of severely constraining our perception of a problem and its potential solutions"); Nash, supra note 15, at 316 (concluding that "the precise way in which a problem or choice is presented-i.e., its frame-may affect the decisionmaker's perception of the problem or choice, and ultimately the decisionmaker's preference"); Phantom Torts, supra note 13, at 292-94 (applying metonymy to show how reducing the concept of "justice" to mean a U.S. trial secured via a blocking statute led to the ironic result of no meaningful trial in a U.S. court)

31. E.g., MaCCORMicK, supra note 20, at 6-7; Francis J. MoOtZ III, LAw, Hermeneutics AND RHETORIC X (2010).

32. KILLINGSWORTH \& PALMER, supra note 17 , at 1 .
} 
While many rhetorical works focus on rhetorica docens, the theory and pedagogy of rhetoric, Killingsworth and Palmer offer Ecospeak as a work of rhetorica utens, the study of rhetoric in use with the purpose of making a practical contribution that can have consequences for public discourse. $^{33}$ The environmental rhetoric first articulated by Killingsworth and Palmer, and applied by numerous scholars over the last twenty years, can therefore provide the theoretical basis to offer practical insight for the resolution of the issues with international environmental tort disputes. We turn first to a summary of concepts from preeminent twentieth century rhetorician Kenneth Burke that forms the core of ecospeak.

\section{A. Kenneth Burke and Dramatism: Terministic Screens, Substance, and Identification}

Burke defines man as the symbol-using animal. ${ }^{34}$ We use a system of symbols and language, not just to name objects or describe concepts, but also to induce action and to get others to identify with a point of view and respond accordingly. ${ }^{35}$ Language is therefore best conceived as symbolic action, with every word imbued with the quality of action-in brief, words have substance, or as Burke parses it, "sub-stance." 36 Speakers take one stance over others through their very choice of words because words are symbols of reality, with each term offering a unique perception of our reality. "Even if any given terminology is a reflection of reality, by its very nature as a terminology it must be a selection of reality; and to this extent it must function also as a deflection of reality." 37 All utterances are therefore "terministic screens" that direct the attention toward one perspective - and away from the potential perspectives created by other terms. ${ }^{38}$ Burke offers the example of a series of photographs taken of the same object, except that the

\footnotetext{
33. Id. at $1-2$.

34. KenNeth Burke, LANGUAGE as Symbolic ACtion: ESSAYS ON LiFe, Literature, AND METHOD 55 (1966) [hereinafter LASA].

35. HENDERSON, supra note 19, at 113-14 ("Value-ridden from the outset, language, for Burke, is intrinsically rhetorical . ...”); see KENNETH BURKE, A RHETORIC OF MOTIVES 38-39, 5758 (1950) [hereinafter Motives]; KenNETH BuRKe, AtTITUDES TOWARD HistoRY 266-67 (1937) [hereinafter ATH].

36. Kenneth Burke, A Grammar of Motives 22 (1945) [hereinafter Grammar] ("Literally, a person's or a thing's sub-stance would be something that stands beneath or supports the person or thing.").

37. LASA, supra note 34 , at 45.

38. Id.
} 
photographer used a different colored filter for each photo. ${ }^{39}$ Although each photo represented the same fact, the different filters revealed notable distinctions. ${ }^{40}$ Language likewise filters the presentation of reality so that "'observations' are but implications of the particular terminology ... the spinning out of possibilities." 41 Because we must use language, we cannot avoid forming terministic screens between ourselves and reality, with each perspective "colored by competing cultural, philosophical, or motivational orientations." 42

The key to Burke's rhetoric is the concept of identification: through the use of symbols, actors identify terms with each other, so that one is substantially the same as the other. This sharing of substance makes the terms consubstantial: "For substance, in the old philosophies, was an act; and a way of life is an acting-together; and in acting-together, men have common sensations, concepts, images, ideas, attitudes that make them consubstantial."43 Implied in identification is its ironic counterpart, division, for in understanding the shared substance of two things, we also realize that those two things are indeed separate. ${ }^{44}$ The choice of the essential term is a rhetorical move: "one may deflect attention from scenic matters by situating the motives of an act in the agent... or conversely, one may deflect attention from the criticism of personal motives by deriving an act or attitude not from traits of the agent [but] from the nature of the situation." 45

\section{B. Ecospeak}

The positions taken by stakeholders in environmental issues are due partially to different ethics and epistemologies, with groups holding separate and conflicting interests based on each group's unique set of values. ${ }^{46}$ Rhetoricians like Killingsworth and Palmer recognize that these differences - and the difficulties in overcoming them - are also a problem of discourse. ${ }^{47}$ "All groups have a particular perspective and use a specialized language developed specifically to describe and stimulate the practices characteristic of their particular outlook on the

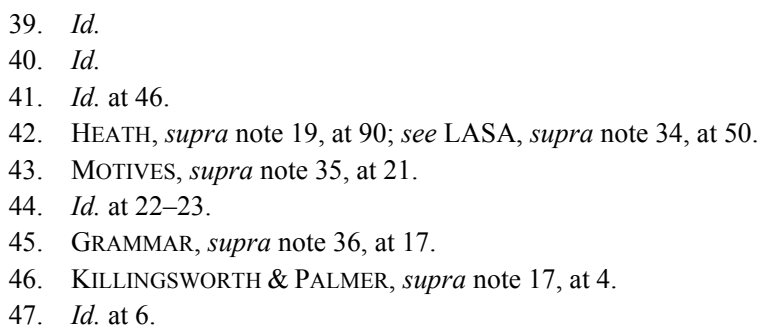


world." ${ }^{48}$ Drawing upon Kenneth Burke's concept of identification, the authors posit that each group has an "identifying story: I (or we) do this." 49 Those outside of the subject position (we) are not part of the narrative because they belong to other groups (you or they). ${ }^{50}$ To tell their story and thereby construct relationships with different groups for cooperative social action, members of the group must employ rhetorical appeals, "enlargements of the we category or mergers of two or more categories, with the ultimate goal being the identification of the 'global' public with the 'local' discourse community." 51 When these rhetorical appeals succeed, the group achieves an identity of interests by sharing its terms - its substance - with others, who act by accepting the group's perspective. ${ }^{52}$ With many environmental issues, however, these appeals often fail, leading to "divisions that harden with time and with the repetition of rhetorical situations whose narrative outlines contain similar plots and characters." 53 The intractability of the environmental dilemma therefore results from the inability of the discourse communities to identify adequately with each other. ${ }^{54}$

Such failed appeals are "the region of ecospeak, where public divisions are petrified, conflicts are prolonged, and solutions are deferred by a failure to criticize deeply the terms and conditions of the environmental dilemma." 55 Ecospeak is a type of shorthand, "a makeshift discourse for defining novel positions in public debate." rhetoric of ecospeak reveals that many environmental debates degrade to "oversimplified dichotom[ies]," such as between environmentalists on one side and developmentalists on the other. ${ }^{57}$ The former "seek longterm protection of endangered environments regardless of short-term economic costs," while the latter "seek short-term economic gain regardless of the long-term environmental costs."

This dichotomy between white hats and black hats is not a matter of historical necessity so much as "a device of discourse used by one side or

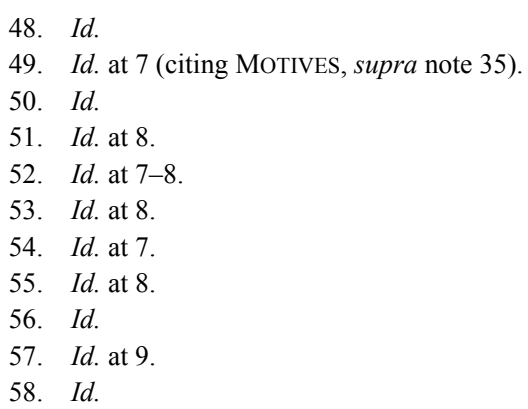


the other (often both) to mobilize forces against a palpable villain." ${ }^{, 59}$ Therein lies the problem with using the shorthand of ecospeak to explore complex environmental issues: "its characteristic terminology and working rhetoric will cause oppositions to close into an irresolvable set of conflicts." ${ }^{60}$ Like Newspeak from George Orwell's 1984, "ecospeak becomes a form of language and a way of framing arguments that stops thinking and inhibits social cooperation rather than extending thinking

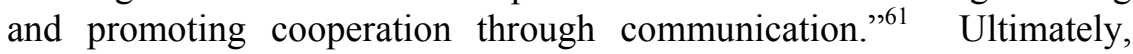
ecospeak conceals other sources of solidarity and of conflict that, if more closely examined, could reveal what is needed to cut through environmental dilemmas:

Further rhetorical analysis breaks the hold of ecospeak by identifying various discourses on the environment before they are galvanized by dichotomous political rhetoric. It does so too by studying the transformations of these discourses as they enter the public realm by way of a local discourse community.... At the very least, such analysis can reveal possible identifications and real conflicts passed over by an ever-too-glib retreat into ecospeak. ${ }^{62}$

"As a first step beyond the simple dichotomy of environmentalist versus developmentalist," Killingsworth and Palmer describe a framework of six different stakeholders in public environmental issues: traditional or mainstream science, government, business and industry, agriculture, social ecology (humanistic environmentalism), and deep ecology (wilderness ethic, nature mysticism). ${ }^{63}$ Rather than "absolute opposites," these six occupy a continuum of environmental interests, with science at one extreme viewing nature as object and deep ecologists on the other viewing nature as spirit; in the middle, business and industry and agriculture view nature as a resource. ${ }^{64}$ Where those employing ecospeak "seek to achieve a measure of control over an audience . . . by categorizing an opponent into a single role," the continuum of multiple shareholders suggests far more complexity-and therefore the possibilities that one stakeholder might hold both different and shared perspectives with another stakeholder. ${ }^{65}$ For example, the methods of science, the sovereignty of government, and the resources of business

\footnotetext{
59. Id. at 10 .

60. Id. at 8 .

61. Id. at 9 .

62. Id. at 10 .

63. Id. at $10-11$

64. Id. at $10-12$.

65. Id. at $11-12$.
} 
and industry tend to put them in a more dominant position than the other three and suggest sources of opposition, as when agricultural interests oppose industrial development. ${ }^{66}$ But agriculture also depends upon industrial hardware and pesticides, and of course some agricultural enterprises are themselves big business. ${ }^{67}$ Sources of tension abound; for example, while business sometimes opposes governmental regulation, it also sometimes works with government to develop natural resources. ${ }^{6}$ Rhetorical appeals can therefore flow in numerous directions "to overcome oppositions and divisions either by forming new solidarities, by reinforcing old ones, or by revealing distances or likenesses in order to transform attitudinal conflicts into political action." ${ }^{\prime 69}$

\section{Environmental Rhetoric Applied in the Humanities and Law}

Rhetoricians over the last twenty years have continued to draw upon and expand Ecospeak and its Burkean foundation to critique public environmental issues. ${ }^{70}$ Herndl and Brown write that we cannot even approach the environment apart from the language that we use to represent it." Accordingly, "rhetoric and its analytic methods can help us understand the nature of our environmental debates and their outcomes." 72 Of particular interest is how issues are framed: the simple dichotomies of "environmental discourse [are] not as straightforward as" presented by stakeholders, so analyses of environmental rhetoric can penetrate the "details of a text and consider[] its relation to the context in which it circulates."73 From this understanding a guide for rhetorical practice in the future can arise, with that rhetorical practice including law. $^{74}$

\footnotetext{
66. Id. at $14-16$.

67. Id. at 17 .

68. Id. at $16-17$.

69. Id. at 17 .

70. E.g., Goggin, supra note 17 , at 5 ("Environmental rhetorics ... tend to contribute to polarizing public opinion on environmental concerns and engender divisive discourse that Killingsworth and Palmer term 'ecospeak."'); Nancy W. Coppola, Rhetorical Analysis of Stakeholders in Environmental Communication: A Model, in TeCHNICAL COMMUNICATION, Deliberative RHETORIC, AND ENVIRONMENTAl DisCourse: ConNeCTIONS AND DiReCTIONS 21, 23-25 (Nancy W. Coppola \& Bill Karis eds., 2000) ("Reliance on these potent symbols shortcircuits our thinking and creates dysfunctional communication and a simplistic response to environmental problems").

71. Herndl \& Brown, supra note 18, at 3.

72. Id. at $9-10$.

73. Id. at $5-10$.

74. Id. at 18 ("Discussions of environmental matters now not only occupy entire fields of study, but cross disciplinary boundaries and include ... law").
} 
A recent essay by Rick Carpenter is typical of the approach to environmental rhetorical analysis. In the public debate about a proposed biomass electric generating plant in Valdosta, Georgia, stakeholders "aligned in terms of a supporter and opponent binary," with their discourse often taking the form of ecospeak. ${ }^{75}$ Such discourse was too simplistic, however, because the conflict actually involved a range of interests in the plant. ${ }^{76}$ Through an explication of the arguments made by competing sides, Carpenter concludes that opponents of the plant prevailed because they understood the multiple and competing ways in which the conflict was situated. ${ }^{77}$ Rather than be divided over a fragmentation of interests, the opponents took advantage of that ambiguity to unite for "broad-based collective action." 78 They fought to establish their credibility and right to be heard in the face of decisionmakers labeling them a "fringe group." 79 In relying on such labels, the Iproponents "construed the[] audience in narrow, exclusionary ways." "In assuming an unproblematic, uncomplicated common identity for their audience, rhetors can neglect to foster identification, which, as Kenneth Burke asserts, is always a rhetorical activity." 81 Though Carpenter analyzed a community debate to show how identities are located and socially produced, he asserts that national identity is likewise a rhetorical construct. ${ }^{82}$ The concept of the nation-state is a rigid conception that creates "a monolithic social space, a common sense of place and thus of self." 83

In another recent work, Michael Burger applied ecospeak, environmental rhetoric and other forms of ecocriticism to examine U.S. environmental litigation. Although he draws primarily from literature, including narrative and allegory, Burger also cites to rhetoric and to Ecospeak in claiming that "story, narrative and rhetoric are essential not only to environmental discourse in general, but also to environmental legal discourse in particular." ${ }^{\prime 4} \mathrm{He}$ explicates the ways that attorneys and judges establish, frame, narrate and argue their cases at various stages in actual litigation "to uncover how we identify and define

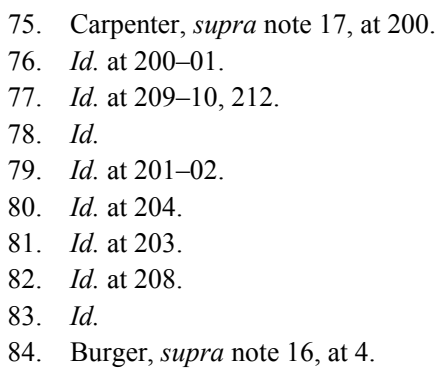


problems (and problem-makers), how we conceive desirable goals (and goal-achievers) and how we craft solutions." ${ }^{~} 85$ As with scholars in the humanities, he writes that environmental debate is a "process of community- and identity-formation." ${ }^{, 86}$ Ecocritical techniques therefore help to expose marginalized meanings and the multiplicity of actors involved in those debates. ${ }^{87}$ Burger describes the allegories employed in environmental debates, the recurring stories and tropes like the pastoral, wilderness and wildness, the environmental apocalyptic, and toxic tales that participants use to frame their arguments. ${ }^{88}$ He then applies these allegories to two different sets of environmental litigation, one dealing with the reintroduction of gray wolves in the Northern Rocky Mountains and the other a public nuisance lawsuit brought by two well-coordinated groups against power companies for carbon dioxide emissions. ${ }^{89}$ Burger uses a close reading of the pleadings, motions, and judicial opinions to demonstrate how the various stakeholders employed the allegories and why those strategies were, or were not, successful. ${ }^{90}$

For example, the nuisance lawsuit was brought by several states and the City of New York against five power companies. ${ }^{91}$ The complaint contains a number of allegories, primarily the environmental apocalyptic, but also framing strategies in which the consortium of states modify the usual binary of environmentalist versus developmentalist by portraying themselves - and therefore the people they represent - as victims of environmental pollution. ${ }^{92}$ Rather than answer the complaint, and thus respond to the substantive climate change argument, the power companies filed a motion to dismiss based upon standing and separation of powers. ${ }^{93}$ By recasting the argument-including that multiple political actors are involved in pursuing their approach to this complex issue - the power companies created a more mundane issue that the district court adopted in a straightforward political question doctrine analysis. ${ }^{94}$ The language of the district court is strongest in discussing standing and policy but shifts to distancing strategies when alluding to

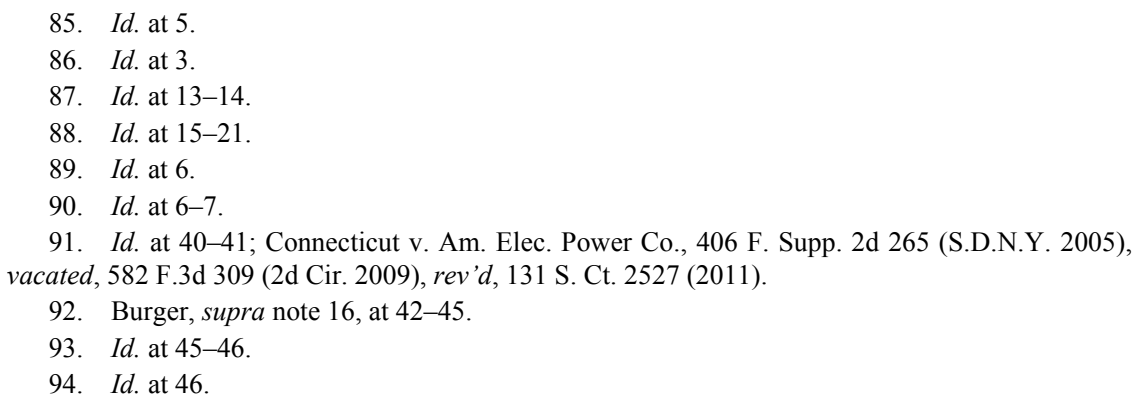


the facts in the complaint. ${ }^{95}$ The Second Circuit reversed in a 140-page opinion that in many places adopted the language of the states' allegory. ${ }^{96}$ Burger concludes "that courts can and do respond to" environmental tropes employed by parties, so ecocriticism can inform the scholarly understanding of environmental law. ${ }^{97}$

Before turning to rhetorical criticism of key texts, this Article first summarizes the complex Lago Agrio proceedings and then analyzes the scholarly criticism against doctrines that limited individual access to courts and other forums in those proceedings.

\section{The LAGO Agrio ProceEdings: A BRIEF HISTORY}

\section{A. Oil Operations in Ecuador and the Aguinda Lawsuit}

In 1964, the Republic of Ecuador allowed Texaco Petroleum Company (TexPet), a subsidiary of Texaco, to begin oil exploration in the Amazon basin. ${ }^{98}$ That part of Ecuador, the Orienté region, was remote from other parts of the country and was populated primarily by a number of indigenous peoples: the Kichwa, Huaorani, Cofan, Secoya, Siona, and Tetetes. ${ }^{99}$ The following year, Ecuador granted TexPet a petroleum concession for a consortium that it owned in equal shares with Gulf Oil Corporation. ${ }^{100}$ The consortium extracted, refined, and shipped crude oil from the Lago Agrio field in exchange for paying royalties to Ecuador. ${ }^{101}$ The Republic of Ecuador joined the consortium through its state-owned oil company PetroEcuador, which acquired Gulf's interests in 1974. ${ }^{102}$ TexPet's activities in the consortium declined, first in 1990 when PetroEcuador assumed TexPet's operation of a trans-Ecuadoran oil pipeline and drilling activities, ${ }^{103}$ then in 1992 when TexPet relinquished its interests in the consortium, thereby leaving PetroEcuador as the sole owner and operator in Lago Agrio since 1992. ${ }^{104}$

\footnotetext{
95. Id. at $45-48$.

96. Id. at $48-53$.

97. Id. at $56-57$.

98. Chevron Corp. v. Donziger, 768 F. Supp. 2d 581, 597 (S.D.N.Y. 2011), rev'd sub nom. Chevron Corp. v. Naranjo, 667 F.3d 232 (2d Cir. 2012).

99. Kimerling, supra note 2, at 459.

100. Chevron Corp. v. Donziger, 974 F. Supp. 2d 362, 386 (S.D.N.Y. 2014).

101. See Kimerling, supra note 2, at 417.

102. Id. at $419-20 \&$ n. 17 .

103. Chevron, 768 F. Supp. 2d at 597.

104. Chevron, 974 F. Supp. 2d at 386.
} 
Shortly after TexPet ceased operations, a group of 46 named plaintiffs represented by U.S. attorneys Steven Donziger and Cristobal Bonifaz filed Aguinda v. Texaco, Inc. in the Southern District of New York. ${ }^{105}$ This putative class action, on behalf of 30,000 indigenous people from Ecuador, ${ }^{106}$ alleged a number of tortious acts-leaking oil from the pipeline, deliberately spraying oil on the roads, and storing petroleum wastes in open pits. ${ }^{107}$ They claimed that these actions led to the pollution of "the rain forests and rivers" and to adverse health effects to residents. ${ }^{108}$ The plaintiffs sought money damages as well as equitable relief like funding for environmental remediation, renovating or closing the trans-Ecuador pipeline, establishing standards for future oil development, and medical monitoring. ${ }^{109}$ The court never addressed the merits of the complaint; instead, the next decade focused on two rounds of hearings over Texaco's motion to dismiss for FNC.

Plaintiffs sued only Texaco, not its TexPet subsidiary or PetroEcuador - the entities that actually operated the consortium. ${ }^{110}$ Nor was the Republic of Ecuador a party. ${ }^{111}$ Initially, Ecuador opposed the lawsuit as an affront to its sovereignty, ${ }^{112}$ but then various Ecuadoran officials showed their support for litigation in the United States as the "only" way to bring a solution to the plaintiffs" situation. ${ }^{113}$ The district court nevertheless ordered dismissal on the grounds of comity and FNC, as well as on the independently sufficient ground of failure to join an indispensable party-PetroEcuador and the Republic of Ecuador. ${ }^{114}$ Judge Jed S. Rakoff reasoned that without these parties, the equitable relief requested, "would be unenforceable on its face, prejudicial to both present and absent parties, and an open invitation to an international

105. See Aguinda v. Texaco, Inc., 142 F. Supp. 2d 534 (S.D.N.Y. 2001), aff'd, 303 F.3d 470 (2d Cir. 2002); Chevron, 768 F. Supp. 2 d at 597.

106. Aguinda v. Texaco, Inc., 303 F.3d 470, 473 (2d Cir. 2002). Another lawsuit was consolidated with Aguinda. See id. at 473-74 (citing Jota v. Texaco, Inc., No. 94 Civ. 9266, 2000 WL 122143 (S.D.N.Y. Dec. 28, 1994)). Peruvians living downstream also brought actions against Texaco that were consolidated with Aguinda. See Aguinda, 142 F. Supp. 2d at 537; Aguinda, 303 F.3d 470, 473.

107. Kimerling, supra note 2, at 450-51; see Aguinda, 142 F. Supp. 2d at 537; Chevron, 768 F. Supp. 2d at 597.

108. See Aguinda, 303 F.3d at 473.

109. Id. at $473-74$.

110. Aguinda, 142 F. Supp. 2d at 537-38.

111. Id. at 537.

112. Jota v. Texaco, 157 F.3d 153, 156 (2d Cir. 1998).

113. Id. at 158 .

114. Id. at 155 . 
political debacle."115 After an election and change of administration in Ecuador, the Republic of Ecuador filed a motion to intervene, which was denied because Ecuador refused to waive sovereign immunity to potential crossclaims from the plaintiffs and counterclaims from Texaco. ${ }^{116}$

Finding that pretrial discovery had produced no evidence that Texaco itself was involved in the operations in Ecuador, Judge Rakoff ordered dismissal. ${ }^{117}$ The Second Circuit vacated and remanded because the dismissal was not conditioned on Texaco consenting to jurisdiction in Ecuador, and because the trial court had relied too heavily on determinations of the Southern District of Texas in weighing the FNC factors. ${ }^{118}$ The Second Circuit also wrote that the court had to consider Ecuador's changed position in re-evaluating comity and that the failure to join an indispensable party might not apply to all of the equitable relief requested. ${ }^{119}$ The court agreed that Ecuador must fully relinquish any claim to sovereign immunity to intervene, but nonetheless remanded this motion for reconsideration as well. ${ }^{120}$

On remand, the Republic of Ecuador declined to participate in U.S. proceedings and refused to waive sovereign immunity. ${ }^{121}$ Texaco, on the other hand, stipulated to submit to the jurisdiction of Ecuadoran courts and then renewed its FNC motion. ${ }^{122}$ As a preliminary matter, Judge Rakoff considered the adequacy of the Ecuadoran courts, including further briefing on "whether the courts of Ecuador ... are sufficiently independent and impartial to provide the requisite modicum of due process." "123 The parties, the U.S. State Department, and the Republic of Ecuador all submitted papers. ${ }^{124}$ Judge Rakoff found them "of little use" because they contained "broad, conclusory assertions as to the relative corruptibility or incorruptibility of the Ecuadorian courts, with scant reference to specifics, evidence, or application to the instant cases." 125 He cited six particulars to support his conclusion that corruption and

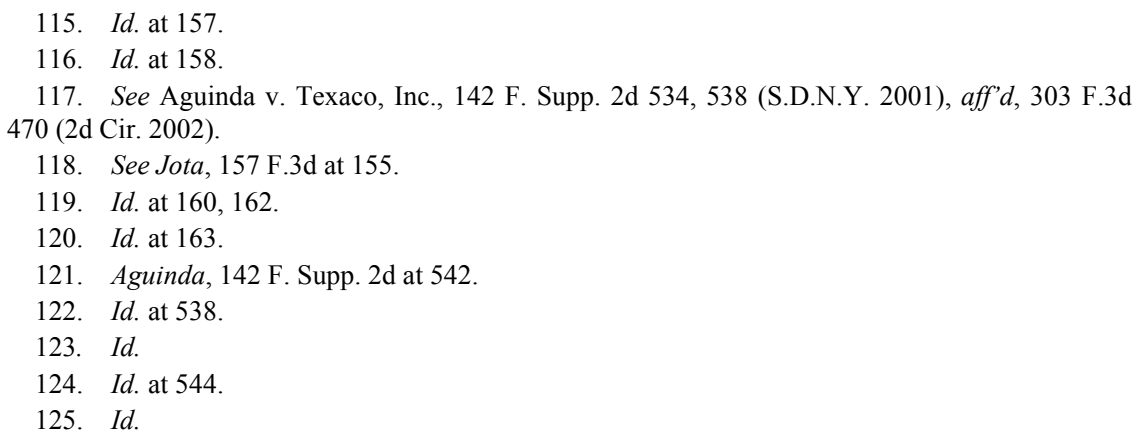


politicization would not affect the instant proceedings, notably that there were no allegations of bias in favor of multinational defendants and none of the documentation of corruption related to civil proceedings. ${ }^{126}$

Having determined the existence of an available and adequate forum, the trial court then turned to the private and public interest factors. ${ }^{127}$ Under the private interest factors, Judge Rakoff cited the "glaring facts that neither the Government of Ecuador nor PetroEcuador . . . are parties to the instant suits, whereas they could be joined in any similar suit brought in Ecuador." 128 He again referred to the Ecuadoran government in considering the public interest factors, characterizing the dispute as Ecuadoran rather than American because the oil development activities at issue were based on "a conscious choice made by the Government of Ecuador in order to stimulate its economy." "129 Finding that on balance these factors favored litigating in Ecuador, Judge Rakoff ordered dismissal. ${ }^{130}$

The Second Circuit affirmed. As to the plaintiffs' contention that Ecuadoran courts are subject to corruption and impartiality, the court listed each of the six "detailed findings" by Judge Rakoff and concluded, "We cannot say that these findings were an abuse of discretion." 131 As to the private interest factors, the court characterized as "significant" the fact that Ecuador and PetroEcuador could be joined in Ecuadoran but not U.S. courts, thus depriving a U.S. court of the ability to order several aspects of the equitable relief sought. ${ }^{132}$ The Second Circuit concluded that the district court was within its discretion in making these findings. ${ }^{133}$

126. Id. at $544-45$.

127. The private interest factors are "the relative ease of access to sources of proof; availability of compulsory process for attendance of unwilling, and the cost of obtaining attendance of willing, witnesses; possibility of view of premises, if view would be appropriate to the action; and all other practical problems that make trial of a case easy, expeditious and inexpensive." Gulf Oil Corp. v. Gilbert, 330 U.S. 501, 508 (1947), superseded by statute, 28 U.S.C. § 1404(a) (2012) (granting courts more discretion to transfer rather than dismiss). The public interest factors are administrative difficulties from the congestion of court dockets; the "local interest in having localized controversies decided at home"; the burden placed on a jury required to decide a case with no connection to the community; and the appropriateness of having the dispute tried in a forum familiar with the governing law rather than having another court untangle conflicts of law and apply foreign laws. Id. at $508-09$.

128. Aguinda, 142 F. Supp. $2 \mathrm{~d}$ at 551.

129. Id. at 551 .

130. Id. at 554 .

131. Aguinda v. Texaco, Inc., 303 F.3d 470, 478 (2d Cir. 2002).

132. Id. at 479 .

133. Id. at 480 . 
B. Simultaneous Activities in Ecuador: Settlement Agreements between Ecuador and Texaco, and a New Ecuadoran Law to Benefit Plaintiffs

While the dismissal of Aguinda was still being passed between the federal courts in New York, activities in Ecuador would affect these and later proceedings. First, as part of relinquishing its stake in the consortium, TexPet entered into a Memorandum of Understanding with Ecuador that it would be released from any potential claims for environmental harms once it completed remediation of the operational sites. ${ }^{134}$ Ecuador and TexPet then signed a series of agreements in 1994 and 1995 for the environmental remedial work. ${ }^{135}$ TexPet contracted with Woodward Clyde International and Smith Environmental Technologies to conduct its share of the $\$ 40$ million remediation program (Ecuador had agreed that PetroEcuador would assume responsibility for part of the remediation). ${ }^{136}$ TexPet completed its remediation in 1998, for which the Ecuadoran government issued an acta that certified completion of remedial obligations under the 1995 agreement. ${ }^{137}$ Ecuador and PetroEcuador on September 30, 1998, signed the final release of TexPet, Texaco, and their subsidiaries and successors from all present and future claims related to operations of the consortium. ${ }^{138}$

Second, representatives of the Aguinda plaintiffs also negotiated with representatives of the Ecuadoran government. For example, when Judge Rakoff first ordered dismissal for failure to join an indispensable party, plaintiffs approached the Ecuadoran government to encourage its motion to intervene. ${ }^{139}$ In exchange, plaintiffs gave Ecuador and PetroEcuador a judgment reduction agreement to protect them from Texaco's potential claims for contribution. ${ }^{140}$ Then, with the possibility that the action would be dismissed from U.S. courts, plaintiffs' representative Cristobal Bonifaz worked with Ecuador to secure passage of new legislation similar to the U.S. superfund law. ${ }^{141}$ The legislation was enacted in Ecuador's Environmental Management Act of 1999 (the EMA), which "created a private right of action for damages for the cost of remediation

\footnotetext{
134. Chevron Corp. v. Donziger, 974 F. Supp. 2d 362, 386-87 (S.D.N.Y. 2014).

135. Kimerling, supra note 2, at 493.

136. Id. at $493-98$.

137. Chevron, 974 F. Supp. $2 \mathrm{~d}$ at 387.

138. Id. For a detailed account of these agreements and the type of remedial work that was actually undertaken, see Kimerling, supra note 2, at 493-514.

139. Chevron, 974 F. Supp. 2d. at 389.

140. Id. at 390

141. Id. at 391 .
} 
of environmental harms generally, as distinct from personal injuries or property damages to specific plaintiffs." ${ }^{142}$ Rather than a class action, the EMA provided plaintiffs something analogous to a citizens' attorney general suit. Baker and Parise characterize the EMA as an attempt by Ecuador "to circumvent the previous settlement with and release of Texaco." 143

\section{The Ecuadoran Judgment and Chevron's Preemptive Suit for Non- Recognition}

Because of the EMA, Aguinda did not die following dismissal but was refiled in Ecuador in 2003-with notable changes from the U.S. suit. ${ }^{144}$ The same named plaintiffs pursued some individual claims, such as compensation for medical treatment, but most of the damages were for environmental remediation on behalf of Ecuador. ${ }^{145}$ The defendant also changed: Chevron had acquired Texaco in 2001, and the latter remains a wholly owned subsidiary of Chevron. ${ }^{146}$ The court-appointed neutral expert opined that the court should award $\$ 27$ billion in damages; ${ }^{147}$ the trial court instead entered judgment for approximately $\$ 8.6$ billion, a figure that was doubled to $\$ 18$ billion when Chevron declined to apologize within two weeks of the judgment, as well as costs to the Amazon Defense Front to administer the proceeds. ${ }^{148}$ Of note, the lion's share of this judgment would go directly to the government of Ecuador for remediation of groundwater, drinking water, and soil, as well as damages to flora and fauna and delivery of health care. ${ }^{149}$

Even before the judgment was announced, Chevron initiated an aggressive strategy of filing numerous section 1782 actions in various U.S. courts to gather evidence with which it could defeat the eventual attempts to enforce that judgment. ${ }^{150}$ These actions were successful, and

\footnotetext{
142. Id.

143. Baker \& Parise, supra note 3, at 9.

144. Chevron Corp. v. Donziger, 768 F. Supp. 2d 581, 599-600 (S.D.N.Y. 2011), rev'd sub nom. Chevron Corp. v. Naranjo, 667 F.3d 232 (2d Cir. 2012); see Drimmer \& Lamoree, supra note 3 , at $502-03$.

145. Chevron, 768 F. Supp. $2 \mathrm{~d}$ at 600.

146. Id. at 594 n.2.

147. Id. at 603 n. 60 .

148. Id. at 621 .

149. Id. The Ecuadoran National Court subsequently eliminated the punitive damages so that the final judgment was approximately $\$ 8.646$ billion in damages. Chevron Corp. v. Donziger, 974 F. Supp. 2d 362, 540 (S.D.N.Y. 2014).

150. Chevron Corp. v. Naranjo, 667 F.3d 232, 236-37 (2d Cir. 2012) (citing 28 U.S.C. § 1782 (2012)).
} 
Chevron gained access to Donziger's personal litigation files as well as over 600 hours of outtakes from the documentary Crude, a feature about Donziger and his campaign on behalf of the plaintiffs. ${ }^{151}$ This evidence included the "Invictus" memo from a law firm retained by plaintiffs, Patton Boggs LLP, which suggested that plaintiffs engage in numerous worldwide actions rather than a single enforcement action in the United States. ${ }^{152}$ The rationale was that a campaign of attaching Chevron assets, and thereby disrupting its activities, would lead to a settlement and be faster than a U.S. recognition and enforcement action. ${ }^{153}$ Chevron therefore filed a preemptive suit in the Southern District of New York against the plaintiffs and their attorneys, alleging claims under the Racketeer Influenced and Corrupt Organizations Act (RICO); state tort claims including fraud; state claims for civil conspiracy; violations of the New York Judiciary Law by Donziger and his law firm; and "a declaratory judgment, pursuant to the federal Declaratory Judgment Act, that the Lago Agrio judgment is not entitled to recognition or enforcement in the United States or anywhere else." ${ }^{\text {"154 }}$ The gist of Chevron's complaint was that the judgment was the product of a judicial system that does not afford due process and was procured by the fraudulent scheme of plaintiffs' attorneys. ${ }^{155}$

The first significant moment in the U.S. proceedings was a temporary injunction preventing plaintiffs and their attorneys from having the judgment enforced anywhere in the world. ${ }^{156}$ The trial court found an immediate and irreparable injury based upon the plaintiffs' Invictus strategy. ${ }^{157}$ The court also found that Chevron would likely succeed on the merits of its claims and win a declaratory judgment that the foreign judgment was not entitled to recognition and enforcement. ${ }^{158}$ The court addressed two grounds under New York's Foreign Money Judgment Recognition Act: the mandatory ground of systemic inadequacy in the courts of Ecuador and the discretionary ground of fraud in the procurement of the judgment. ${ }^{159}$ For the first ground, the court relied upon expert testimony and reports from the U.S. Department

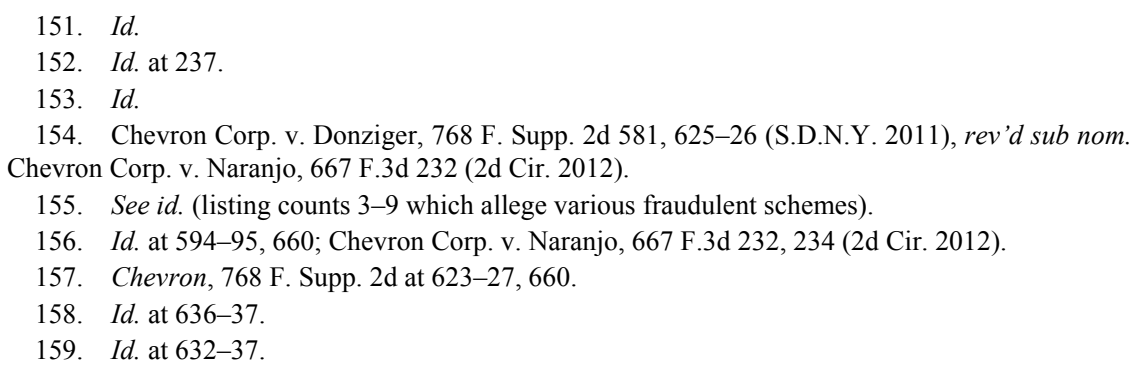


of State and from international non-governmental organizations about systemic corruption and politicization in the courts of Ecuador. ${ }^{160}$ For the second ground, the alleged acts of misconduct included pressuring and bribing Ecuadoran judges and other government officials and ghostwriting the report of the supposedly neutral court-appointed expert upon which the damages were based. ${ }^{161}$ The Second Circuit reversed and dismissed the preliminary injunction, ruling that the grounds for nonrecognition under New York's Recognition Act could be raised only defensively by the judgment debtor and not offensively under the Declaratory Judgment Act. ${ }^{162}$ The Second Circuit noted several times that allowing this approach would cause unnecessary friction between courts of the U.S. and of other countries. ${ }^{163}$

On remand, Chevron dropped all claims for damages and limited the relief it sought. ${ }^{164}$ It narrowed the injunction to prevent Donziger and two of the judgment creditors over whom the court had jurisdiction from profiting from the alleged fraud, and to enjoin enforcement only in the United States rather than worldwide, thus avoiding issues of comity or international relations. ${ }^{165}$ By seeking only injunctive relief, Chevron paved the way for a bench trial, which occurred in October and November of 2013. ${ }^{166}$ On March 4, 2014, Judge Kaplan issued his staggeringly long opinion in which he granted the injunction based upon fraud on the court, violations of RICO, and violations of state law. ${ }^{167}$ While a detailed explication of the findings of fact is beyond the scope of this Article, Judge Kaplan's summary of the fraud offers a sense:

They submitted fraudulent evidence. They coerced one judge, first to use a court-appointed, supposedly impartial, "global expert" to make an overall damages assessment and, then, to appoint to that important role a man whom Donziger hand-picked and paid to "totally play ball" with the LAPs 「Lago Agrio Plaintiffs]. They then paid a Colorado consulting firm secretly to write all or most of the global expert's report, falsely presented the report as the work of the court-appointed

160. Id. at $616-20$.

161. E.g., id. at 635-37. For more about the district court's findings and about the parties' outof-court tactics, see Drimmer \& Lamoree, supra note 3, passim; Rhetoric of Recognition, supra note 4 , at $254-55$.

162. Chevron Corp. v. Naranjo, 667 F.3d 232, 234, 240 (2d Cir. 2012).

163. Id. at 242, 246; see Rhetoric of Recognition, supra note 4, at 264-65 (discussing the Second Circuit's awareness of the international relations implications of affirming a holding that Ecuador's entire judiciary was corrupt).

164. Chevron Corp. v. Donziger, 974 F. Supp. 2d 362, 383-86 (S.D.N.Y. 2014).

165. Id.

166. Id.

167. Id. passim. 
and supposedly impartial expert, and told half-truths or worse to U.S. courts in attempts to prevent exposure of that and other wrongdoing. Ultimately, the LAP team wrote the Lago Agrio court's Judgment themselves and promised $\$ 500,000$ to the Ecuadorian judge to rule in their favor and sign their judgment. If ever there were a case warranting equitable relief with respect to a judgment procured by fraud, this is it. ${ }^{168}$

While Judge Kaplan recognized the environmental harm in the Orienté, and even the potential responsibility of Texaco and Chevron for some of that harm, he ruled that Donziger and his clients "were not entitled to corrupt the process to achieve their goal," no matter how just their cause. ${ }^{169}$

\section{Parallel Proceedings: International Arbitration Between Chevron and Ecuador}

In addition to judicial proceedings in the United States and Ecuador, this dispute has included actions before international dispute resolution bodies, thus providing a rare glimpse at the possibility for international public law to affect transnational environmental torts. These actions include arbitration brought by Chevron and Texaco against the Republic of Ecuador and PetroEcuador, and a request for preliminary measures filed by the Lago Agrio plaintiffs with the Inter-American Commission on Human Rights (IACHR) against Ecuador. ${ }^{170}$

In 1993, the United States and Ecuador signed a BIT that entered into force on May 11, 1997, "to promote greater economic cooperation between them, with respect to reinvestment by nationals and companies of one Party in the territory of the other Party." 171 The provisions of this BIT resemble those of others between the United States and developing countries: they provide for national treatment, offer most-favored-nation status, and address expropriation. ${ }^{172}$ Article VI pertains to investment disputes "between a Party and a national or company of the other party arising out of or relating to ... an investment agreement between that Party and such national or company." 173 Of particular relevance is Article VI(3), which gives the investing company the option "to consent

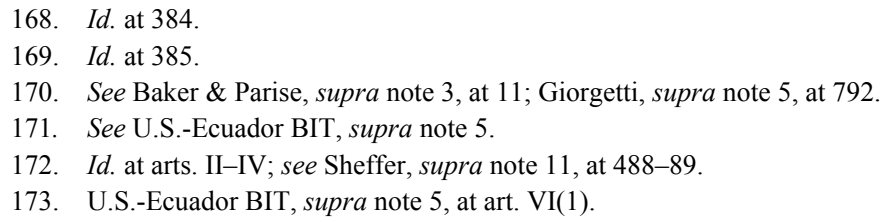


in writing to the submission of the dispute for settlement by binding arbitration," and once that consent is given, "either party to the dispute may initiate arbitration."174 Article VI(6) provides for the consent of both Ecuador and the United States to binding arbitration, which "shall be final and binding on the parties to the dispute."175

Even before the Ecuadoran trial court had issued a judgment in the Lago Agrio proceedings, Chevron and Texaco initiated arbitration pursuant to the BIT on September 23, 2009. ${ }^{176}$ It chose the option of the Arbitral Rules of the United Nations Commission on International Trade Law (UNCITRAL), Texaco and Chevron (Claimants) proposing a panel of three arbitrators and naming its party-appointed arbitrator. ${ }^{177}$ Claimants requested ten different forms of relief, with two forms being of particular importance. ${ }^{178}$ First, they sought a declaration that, pursuant to the remediation agreements from the 1990s, they "have no liability or responsibility for environmental impact... arising out of the former Consortium." "179 Second, they sought "a declaration that Ecuador or PetroEcuador is exclusively liable for any judgment that may be issued in the Lago Agrio Litigation" and "an order and award requiring Ecuador to indemnify, protect and defend Claimants." ${ }^{\text {Es }}$ Essentially, Chevron sought to have the judgment declared null, and in the alternative, to have Ecuador assume responsibility for any payments, most of which would go to Ecuador anyway. ${ }^{181}$

The panel divided the merits of the dispute into two tracks, with the first to resolve Ecuador's contention that Chevron was not a "Releasee" under the 1995 remediation agreements. ${ }^{182}$ On September 17, 2013, the tribunal issued the First Partial Award on Track I. ${ }^{183}$ Applying Ecuadoran law, the panel concluded that the 1995 agreement was intended to release forever all claims - both contractual and environmental — by Ecuador and PetroEcuador against TexPet. ${ }^{184}$ This

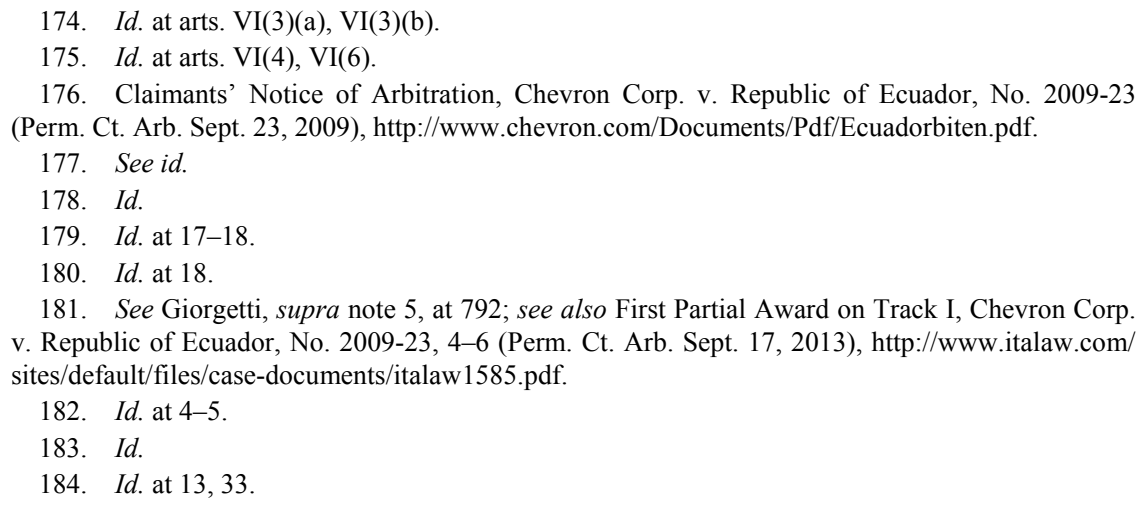


included a release of TexPet, the parent company Texaco, and their "principales $y$ subsidiarias," which the panel concluded extended to potential future parent companies like Chevron. ${ }^{185}$ Issues reserved for Track II included: whether Ecuador breached the remediation agreements, whether the claims of the Lago Agrio plaintiffs were individual, "collective or diffuse," and thus essentially those of Ecuador itself, and the specific effect of the EMA on the remediation agreements. ${ }^{186}$

The panel nonetheless decided that one issue appropriate for Track I was whether the individual plaintiffs could make diffuse claims for environmental harm to Ecuador without also claiming to have suffered personal harm. ${ }^{187}$ The tribunal concluded that under Ecuadoran law at the time of the remediation and settlement agreements, only Ecuador and not individual citizens had the right to bring environmental claims. ${ }^{188}$ Accordingly, only Ecuador had the legal capacity to settle such claimswhich it did through the remediation agreements. ${ }^{189}$ The 1999 EMA, which granted private individuals standing to bring diffuse environmental claims, "could not revive the diffuse right ... which had already been extinguished by the 1995 Settlement Agreement." 190 The tribunal concluded: "It is not juridically possible for a person to exercise a right which no longer exists." 191 At the time of this writing, the tribunal has not ruled on Track II.

In response to the arbitration, the Lago Agrio plaintiffs on February 9, 2012, filed a request with the IACHR against Ecuador. ${ }^{192}$ The request alleged that their "fundamental rights" would be harmed if Chevron obtained a declaration that the judgment was unenforceable. ${ }^{193}$ The plaintiffs sought "precautionary measures from the Republic ... that the Republic will refrain from taking any action that would contravene, undermine, or threaten the human rights of the [plaintiffs]." ${ }^{194}$ In other

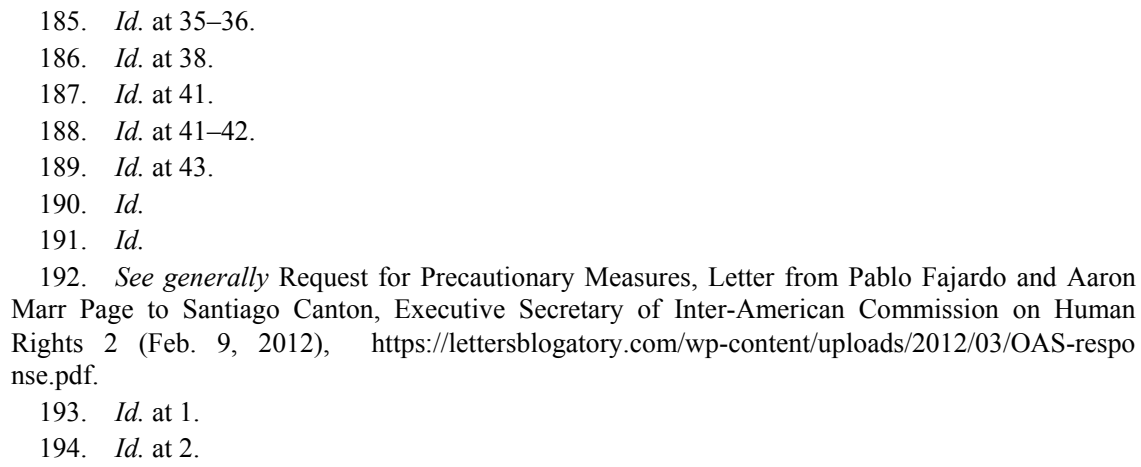


words, they wanted the IACHR to order the Ecuadoran government not to interfere with enforcement of the judgment. ${ }^{195}$ Although the IACHR can grant precautionary measures on a showing of imminent threat and irreparable harm, the plaintiffs withdrew their claims before they could be heard. ${ }^{196}$ Though the reasons are unclear, commentators have speculated "that plaintiffs were reluctant to antagonize Ecuador at this particular juncture of the international arbitration." 197

\section{THE LACK OF ACCESS TO A U.S. FORUM FOR INDIVIDUAL INTERNATIONAL ENVIRONMENTAL TORT CLAIMS AND PROPOSED SOLUTIONS}

Drawing on the example of the Lago Agrio proceedings, Whytock and Robertson opine, "[a]ccess to justice requires not only court access, but also a potential remedy." 198 Foreign plaintiffs are often denied a forum for their environmental tort claims, whether in the United States or their home countries. ${ }^{199}$ Even if they win a judgment, the laws for recognition and enforcement may prevent them from ever collecting. ${ }^{200}$ Numerous commentators have proposed solutions based upon revising FNC and enforcement laws, but these private law solutions introduce other problems and are incomplete; indeed, they may not have even changed the result in the Lago Agrio proceedings. ${ }^{201}$

\section{A. The Problems with FNC and Enforcement Laws}

U.S. courts provide a sophisticated body of substantive and procedural laws, including class actions, open discovery rules, contingency fee contracts, the right to a jury trial, and potentially large damage awards, including punitive damages. ${ }^{202}$ These features have enticed plaintiffs from around the world, in particular from developing countries like Ecuador, to pursue their claims in the United States because their own country's courts do not provide them. ${ }^{203}$ For example, courts in Latin America do not have class actions or broad discovery,

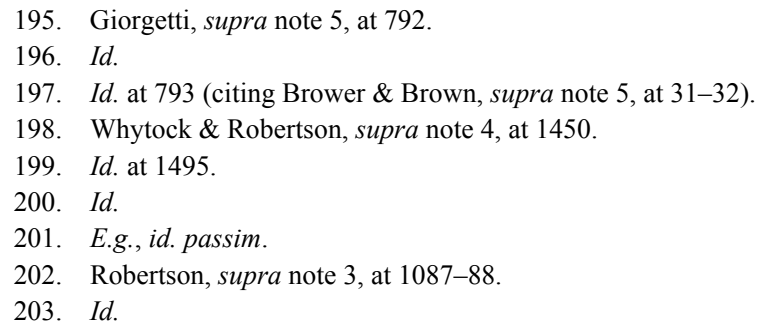


vehicles that are essential to litigate mass tort claims. ${ }^{204}$ These courts do not allow contingency fee contracts with attorneys, and losing parties have to pay the winner's costs and fees ${ }^{205}$ thus making litigation by poor plaintiffs practically impossible. Juries are not common, and awards are just a fraction of what can be recovered in the United States. ${ }^{206}$

These disparities do not render a foreign forum inadequate under the adequacy prong of the FNC analysis, however. U.S. courts routinely find that the foreign courts are adequate because the threshold is low: the parties must not be deprived of a remedy nor be treated unfairly. ${ }^{207}$ Unless the foreign court lacks jurisdiction - to which defendants can stipulate-dismissal is proper, as it was in Aguinda. ${ }^{208}$ The reality, however, is that dismissal is usually outcome determinative. ${ }^{209}$ Many suits like those in Aguinda never get refiled following an FNC dismissal; those that are refiled do not make it to judgment, and settlements are only a fraction of what they would have been in the United States. ${ }^{210}$ Scholars writing at the time of the Aguinda dismissal therefore concluded that the plaintiffs would be denied access to a forum that could provide a meaningful remedy. ${ }^{211}$ Rogge framed it as a social, political, and ethical issue because the alleged tortfeasor is an American company and should thus be held accountable in U.S. courts. ${ }^{212}$ The FNC dismissal was particularly galling to Kimerling, who in a lengthy analysis concluded that the Aguinda trial court based its conclusions on "detailed but questionable factual assumptions" and a "balancing of private and public interest factors" that "was uneven." "13 A number of other scholars have raised this complaint. ${ }^{214}$ It is therefore unsurprising that Van Detta writes about the "illegitimacy," "incoherence," and "lack of principle" of the FNC doctrine. ${ }^{215}$

\footnotetext{
204. Id. at 1088 .

205. Id. at 1085 .

206. E.g., Robertson, supra note 3, at 1087-88; Rhetoric of Recognition, supra note 4, at 236.

207. Rhetoric of Recognition, supra note 4, at 238.

208. Id. at 236; Whytock \& Robertson, supra note 4, at 1456-60.

209. Rhetoric of Recognition, supra note 4, at 238; Phantom Torts, supra note 13, at 304.

210. Rhetoric of Recognition, supra note 4, at 238; Phantom Torts, supra note 13, at 304.

211. E.g., Rogge, supra note 2, at 300-01 (claiming that "the victims of industrial accidents and severe environmental contamination are left totally without legal remedy in either the home or host country"); Van Detta, supra note 2, at 54-56 (characterizing FNC as a "virtually impenetrable barrier").

212. Rogge, supra note 2, at 300-01.

213. Kimerling, supra note 2, at 530

214. See, e.g., Phantom Torts, supra note 13, at 302-04 (summarizing scholars who argue that courts misapply FNC).

215. Van Detta, supra note 2, at 54, 59, 64.
} 
Like other Latin American countries, Ecuador enacted retaliatory legislation in response to FNC dismissals. ${ }^{216}$ Retaliatory legislation takes two basic forms. ${ }^{217}$ The first merely makes the courts of the home country unavailable if a claim is first filed abroad; the purpose of these statutes is to defeat the "available" consideration during FNC proceedings. $^{218}$ Such statutes have not been successful. ${ }^{219}$ The second type of legislation creates procedural mechanisms, minimum damages, and pre-litigation bonds - among other measures - to make the prospect of litigating abroad more risky than remaining in the United States, thus encouraging U.S. multinationals not to move for FNC in the first place. $^{220}$ The EMA is this second type, ${ }^{221}$ although it did not deter Texaco from seeking dismissal. Even with this retaliatory legislation, not all potential plaintiffs have benefitted. For example, the Amazon Defense Front and other plaintiffs' attorneys claim to represent all the indigenous peoples, yet the Kichwa and Huaorani have been excluded from the alliances that participated in the Lago Agrio proceedings. ${ }^{222}$ These tribes attempted to bring their own environmental lawsuit in Ecuador, but that case was rejected. ${ }^{223}$

Even the plaintiffs who won the $\$ 9$ billion judgment never really had a meaningful forum if they can never collect the money. The intersection of FNC and U.S. recognition and enforcement laws create what commentators have variously labeled "boomerang litigation," or the "enforcement loophole," or an "access-to-justice gap." 224 As part of the adequacy determination at the FNC stage, plaintiffs often argue that their home country's judiciary is corrupt and politicized, arguments that the defendants as movants counter. ${ }^{225}$ For example, as discussed in the Section on the Aguinda proceedings, plaintiffs proffered considerable evidence of political turmoil and other types of corruption. ${ }^{226}$ Baker and Parise write that, at the time of Aguinda, Ecuador ranked among the

\footnotetext{
216. Robertson, supra note 3, at 1092-94.

217. Id. at 1093 .

218. Id.

219. Id. at 1093-94.

220. Id.; see Rhetoric of Recognition, supra note 4, at 238, 242-43.

221. Rhetoric of Recognition, supra note 4, at 252-53.

222. Kimerling, supra note 2, at 629.

223. Id. at $629,642-51$.

224. See Casey \& Ristroph, supra note 3, at 22 (boomerang litigation); Weston, supra note 3, at 736 (enforcement loophole); Whytock \& Robertson, supra note 4, at 1472 (access-to-justice gap).

225. Rhetoric of Recognition, supra note 4, at 236.

226. See discussion supra Part III.
} 
worst countries in Latin America for judicial corruption. ${ }^{227}$ For political reasons, however, U.S. courts hesitate to declare the judiciary of an entire country corrupt; thus, during FNC proceedings, "the courts either refuse to inquire into [corruption] of the judiciary, or they appl[y] only minimal scrutiny to ascertain whether the corruption would preclude [fairness] for the individual plaintiffs." 228 In Aguinda, Judge Rakoff rejected the broad and conclusory evidence of corruption because it did not make specific reference to the instant case. ${ }^{229}$ Further, the FNC determination focuses on whether the plaintiff, and not the defendant, will have an adequate forum; ${ }^{230}$ given the government of Ecuador's filings with the trial court in support of the plaintiffs, Judge Rakoff could easily conclude that they would.

A U.S. court again considers the adequacy of the foreign judiciary in an action to recognize and enforce a foreign money judgment. The recognition and enforcement laws of most U.S. states contain a systemic inadequacy ground for mandatory non-recognition if "the judgment was rendered under a system which does not provide impartial tribunals or procedures compatible with the requirements of due process of law."231 Although this ground addresses adequacy, the standards applied differ from those in the FNC proceedings: they are "stricter, defendant-focused, and ex-post." 232 The result is that the same evidence of broad corruption that was not relevant at the FNC stage now becomes determinative of a finding that the foreign forum is inadequate, and thus a mandatory ground for a finding that the foreign money judgment should not be recognized or enforced. ${ }^{233}$ Commentators reasoned that the Lago Agrio plaintiffs would be caught in the access-to-justice gap.

The Second Circuit's dismissal of Judge Kaplan's temporary injunction might suggest that those predictions were overstated, but that holding does nothing to resolve the issue of access to a meaningful forum - and may even make recourse to U.S. courts more problematic. First, the Second Circuit reversed because the New York Recognition

227. Baker \& Parise, supra note 3 , at 13

228. See Rhetoric of Recognition, supra note 4, at 237; see also Whytock \& Robertson, supra note 4 , at $1458-59$.

229. Rhetoric of Recognition, supra note 4, at 237.

230. Whytock \& Robertson, supra note 4, at 1454.

231. UNIF. Foreign MONEY-JUdgMENTS RECOGNITION ACt 13 U.L.A. pt. II, § 4(a)(1) (1962); Unif. Foreign Money-Judgments ReCOGNITION ACT pt. II, § 4(b)(1) (2005); see Rhetoric of Recognition, supra note 4, at 222-23.

232. Whytock \& Robertson, supra note 4, at 1449-50.

233. Casey \& Ristroph, supra note 3, at 21-22. 
Act does not apply offensively; ${ }^{234}$ this holding, therefore, does not apply to the typical action where the judgment creditor brings an action for recognition and enforcement and the judgment debtor raises the ground defensively. The reason that Chevron filed a preemptive suit was because the plaintiffs made the strategic choice not to seek enforcement in the United States - they knew that the systemic inadequacy ground could be used against them, creating a Catch-22. ${ }^{235}$ Second, the court based its holding primarily upon the policy of the New York Recognition Act and engaged in little analysis of the text of the Act. ${ }^{236}$ A close reading of those statutes suggests that an offensive use might be proper. $^{237}$ Because state law governs recognition and enforcement, ${ }^{238}$ and because other courts have allowed preemptive non-recognition, ${ }^{239}$ future judgment debtors could file preemptively in states not covered by the Second Circuit. Rather than a victory for foreign plaintiffs, the Second Circuit's opinion introduces more uncertainty for all parties, as well as rule of law issues. ${ }^{240}$ Third, dismissing the injunction did not end the matter but only highlighted the fact that U.S. laws offer other means for defendants to avoid adverse foreign judgments. In addition to the systemic inadequacy ground, most states have a number of mandatory and discretionary grounds for non-recognition. ${ }^{241}$ And a particularly aggressive and well-funded judgment debtor could follow the lead of Chevron by gathering evidence through section 1782 proceedings and fighting enforcement through other means like the citizens' suit provisions of RICO.

\section{B. Proposed Solutions}

These commentators have offered a number of solutions targeted at changing FNC and the recognition laws to allow foreign plaintiffs greater access to U.S. courts. As a common law doctrine, the courts themselves could potentially exercise their discretion and apply the FNC standards

\footnotetext{
234. Chevron Corp. v. Naranjo, 667 F.3d 232, 240 (2d Cir. 2012).

235. Rhetoric of Recognition, supra note 4, at 254.

236. Chevron, 667 F.3d at 241.

237. Rhetoric of Recognition, supra note 4, at 261-64.

238. Id. at 223; Mandatory, supra note 3, at 24.

239. E.g., InvestorsHub.com, Inc. v. Mina Mar Group, Inc., Case No. 4:11cv9-RH/WS, 2011 U.S. Dist. LEXIS 87566 (N.D. Fla. June 20, 2011); Shell Oil Co. v. Franco, No. CV 03-8846 NM (PJWx), 2005 WL 6184247 (C.D. Cal. Nov. 10, 2005); Matusevitch v. Telnikoff, 877 F. Supp. 1, 2 (D.D.C. 1995).

240. See Rhetoric of Recognition, supra note 4, at 267.

241. See Mandatory, supra note 3, passim; Discretionary, supra note 3, passim.
} 
more strictly to retain more cases. For example, the Supreme Court in Gulf Oil v. Gilbert listed the enforceability of any potential judgment as a private interest factor, yet the Court did not list it in a later case that involved foreign plaintiffs, Piper Aircraft v. Reyno. Further, lower courts rarely apply it. ${ }^{242}$ When the factors present a close call, the balance might be tipped if the U.S. court concludes that a country has a history of judicial politicization and corruption or has enacted retaliatory legislation that might deny due process, and that any potential judgment might be unenforceable. ${ }^{243}$ Whytock and Robertson go farther and urge courts to apply the stricter systemic inadequacy standard from the recognition and enforcement stage to determine the adequacy of the foreign forum during FNC deliberations. ${ }^{244}$ Nothing in Supreme Court precedent prohibits such an inquiry. ${ }^{245}$ The result would be fewer dismissals to countries like Ecuador that have persistent problems with politicization and corruption of the judiciary. ${ }^{246}$ To strengthen this analysis, courts should likewise consider adequacy for both plaintiffs and defendants, thus foreclosing the possibility of dismissal for FNC because plaintiffs would not be denied due process, but then finding nonrecognition of a judgment because defendants were denied due process. ${ }^{247}$ In addition, a U.S. court "should include a "return jurisdiction clause'... if the judgment proves unenforceable," allowing the possibility to relitigate. ${ }^{248}$ Some commentators have even proposed that defendants agree to honor any adverse judgment without waiting for plaintiffs to bring an enforcement action. ${ }^{249}$

For cases originally filed in the United States and dismissed for FNC, a number of commentators argue that judgment debtors should be estopped at the enforcement stage from arguing that the foreign judiciary is inadequate, unless the systemic inadequacy was unforeseeable at the time of dismissal. ${ }^{250}$ Some take a particularly tough stance on foreseeability. For example, a defendant who at the FNC stage

242. Whytock \& Robertson, supra note 4, at 1496-97; see Piper Aircraft v. Reyno, 454 U.S 235, 241 n.6 (1981); Gulf Oil Corp. v. Gilbert, 330 U.S. 501, 508 (1947), superseded by statute, 28 U.S.C. $§ 1404$ (a) (2012).

243. Whytock \& Robertson, supra note 4, at 1496-97.

244. Id.

245. Id. at 1495 .

246. Id. at $1512-13$.

247. Id. at 1496 .

248. Id. at 1499 .

249. Kenney, supra note 3, at 865; Patel, supra note 4, at 106.

250. E.g., Patel, supra note 4, at 106; Weston, supra note 3, at 765; Whytock \& Robertson, supra note 4 , at 1500 . 
maintained that a foreign court was adequate in light of U.S. State Department and other evidence that the governments and courts of developing countries are known to be corrupt should bear the risk of changed conditions like new retaliatory legislation. ${ }^{251}$

Courts necessarily operate on a case-by-case basis, so they are not in the best position to craft a coherent approach to jurisdiction, standing, and forum for environmental tort claims. ${ }^{252}$ Scholars like Robertson advocate for new legislation on the rationale that Congress can provide better standardization and clarity via statutes and can provide a platform for intentional policymaking. ${ }^{253}$ Her ideal FNC legislation would open federal courts to cases brought by foreign plaintiffs. Robertson argues that, "at a minimum ... U.S. district courts [should] presumptively accept a case against U.S. resident defendants as long as jurisdiction and venue are satisfied."254 Dismissal would be allowed only if the other country has an available forum and "the defendant would be unable to present its defenses in the U.S. due to difficulties in obtaining evidence or establishing jurisdiction over parties or witnesses located elsewhere." 255

Van Detta would go beyond revising FNC and instead reject it outright on a corrective justice theory: U.S. multinational corporations receive a benefit from operating abroad while creating non-reciprocal risks for foreign plaintiffs, so U.S. substantive and procedural laws must merge to provide those plaintiffs a forum for redress. ${ }^{256}$ He proposes a preservation-of-court-access statute that conclusively presumes jurisdiction in the United States for corporations that have systematic and continuous minimum contacts here. ${ }^{257}$ Under his proposal, Aguinda should have remained in the Southern District of New York because the role of the parent corporation Texaco was downplayed in the FNC analysis. ${ }^{258} \mathrm{He}$ argues that Texaco could have then brought a separate

251. E.g., Weston, supra note 3, at 765. While Whytock and Robertson make the same argument, they would also change the FNC analysis so that the adequacy standard is consistent. Whytock \& Robertson, supra note 4, at 1494-95, 1505-08. For a concise summary of the difference between judicial and collateral estoppel in the context of FNC and recognition of foreign money judgments, see Walter W. Heiser, Forum Non Conveniens and Retaliatory Legislation: The Impact on the Available Alternative Forum Inquiry and on the Desirability of Forum Non Conveniens as a Defense Tactic, 56 KAN. L. REV. 609, 641-42 (2008).

252. Baker \& Parise, supra note 3, at 45-46; Robertson, supra note 3, at 1084-85.

253. Robertson, supra note 3, at 1121-22.

254. Id. at 1128 .

255. Id.

256. Van Detta, supra note 2, at 59, 64-66.

257. Id. at $68-72$.

258. Id. at 97-99. 
action in the courts of Ecuador for indemnity or contribution from Ecuador and PetroEcuador. ${ }^{259}$

\section{Shortcomings of These Solutions}

Though these proposals could have a beneficial impact upon less complex proceedings, they suffer from a number of shortcomings when considered in light of the mass actions and class actions of environmental tort litigation. Even if FNC were completely removed, some scholars contend that a case like Aguinda would be dismissed anyway. Baker and Parise conclude that it would be dismissed for lack of jurisdiction under traditional conflicts of law balancing because the plaintiffs asserted claims both for personal and for environmental injuries, the latter of which necessarily occurred in Ecuador. ${ }^{260}$

Under the more modest FNC proposals like Robertson's, she would allow for dismissal if the defendant cannot gather evidence from abroad, or if the court cannot establish jurisdiction over a party. ${ }^{261}$ That was the precise situation in the Aguinda proceedings. Texaco would have sought indemnity against the Republic of Ecuador, which refused to consent to jurisdiction in the United States, and refused to sign the Hague Convention on Taking Evidence Abroad in Civil or Commercial Matters, which would therefore require U.S. courts to resort to inefficient methods of gathering evidence like letters rogatory. ${ }^{262}$

The difficulty in gathering evidence speaks to another point — while many scholars make compelling arguments that U.S. defendants should be held accountable in U.S. courts, they downplay or ignore the actual proceedings that would occur if the U.S. court maintained jurisdiction. ${ }^{263}$ After all, the private and public interest factors relate to legitimate concerns for the parties and the courts. ${ }^{264}$ If courts cannot compel

\footnotetext{
259. Id. at 99 .

260. Baker \& Parise, supra note 3, at 28-29.

261. Robertson, supra note 3, at 1128.

262. Ecuador, HAgue CONFERENCE ON PRIVATE INT'L LAw, http://www.hcch.net/index _en.php?act $=$ states.details\&sid $=92$ (last updated Nov. 13, 2014).

263. See, e.g., Martin Davies, Time to Change the Federal Forum Non Conveniens Analysis, 77 TUL. L. REV. 309, 326-27, 333 (2002) (downplaying the Gilbert private interest factors because the Hague Service and Evidence Conventions and new technology afford access to witnesses and evidence located abroad); Patel, supra note 4, at 109-10 (urging U.S. courts to accept cases where the host country is corrupt so that corporations can be held more accountable); Phantom Torts, supra note 13, at 302-05 (summarizing critics of FNC who argue that the private and public interest factors are misapplied and that U.S. corporations can be held accountable only if the claims of foreign plaintiffs are heard in U.S. courts).

264. See, e.g., Jennifer L. Woulfe, Note, Where Forum Non Conveniens and Preemptive
} 
witness testimony and the gathering of documents, this cuts against a fundamental part of U.S. procedure - the provision for broad discovery.

More importantly, the inability of a U.S. court to assert power in a foreign country increases the potential for fraud to infect the proceedings. Consider the DBCP pesticide cases, which share many similarities with the Lago Agrio proceedings. After several cases were dismissed from U.S. courts on FNC grounds, Nicaragua enacted retaliatory legislation with the aid of the plaintiffs' attorneys that allowed for the possibility of huge damage awards. ${ }^{265}$ This legislation was the "impetus" for a fraudulent scheme where U.S. and Nicaraguan attorneys recruited bogus plaintiffs, falsified work and medical documents, coached the plaintiffs to lie, and engaged in tactics of intimidation to prevent witnesses from coming forward. ${ }^{266}$ One case went to trial in Los Angeles and resulted in a judgment for the plaintiffs; only after years of appellate and writ proceedings was the fraudulent scheme uncovered and the judgment vacated. ${ }^{267}$ The trial judge wrote that she had lacked the "power to compel witness testimony or enter other orders that would have uprooted the fraud years earlier." 268 The situation with the EMA and the proceedings conducted thereunder is similar. The EMA was hastily adopted with input from the plaintiffs' attorneys, and its procedural and other mechanisms were not fine-tuned. ${ }^{269}$ "This highly politicized, legally fragile environment is necessarily ripe for manipulation by foreign attorneys on both sides."270

Assuming that Aguinda had gone forward in the United States and resulted in a judgment for plaintiffs, ChevronTexaco would have had to file a separate action in Ecuador to seek indemnity and contribution from the Republic of Ecuador, which runs counter to policies like reducing the multiplicity of proceedings. ${ }^{271}$ Further, any U.S. judgment would be

\footnotetext{
Jurisdiction Collide: An Analytical Look at Latin American Preemptive Jurisdiction Laws in the United States, 30 ST. LouIS U. PUB. L. REv. 171 (2010) (advocating that courts retain current FNC standards).

265. Phantom Torts, supra note 13, at 308-10.

266. Id. at 314-16.

267. Id. at 312-13 (citing Tellez v. Dole Food Co., No. BC 312852 (Cal. Super. Ct. L.A. Cnty. Sept. 7, 2004); Mejia v. Dole Food Co., No. BC340049 (Cal. Super. Ct. L.A. Cnty. Apr. 23, 2009)).

268. Id. at 324

269. Rogers, supra note 4, at 503-05.

270. Id. at 505 .

271. A number of rules of procedure and related judicial doctrines exist to promote judicial economy by requiring the joinder of parties in a single lawsuit. See, e.g., FED. R. CIV. P. 19 (required party joinder); Parklane Hosiery Co. v. Shore, 439 U.S. 322, 329-30 (1979) (stating that one goal of defensive collateral estoppel is to "promote judicial economy" by incentivizing plaintiffs
} 
obtained under procedural rules that allow for broad discovery, while the indemnity trial would be governed by much more circumscribed Ecuadoran procedural rules. It is therefore possible that ChevronTexaco could be liable under U.S. standards but unable to obtain indemnification under Ecuadoran standards. Separate proceedings, especially in different countries that apply different procedural and evidentiary rules, risk inconsistent results. ${ }^{272}$

While revising the recognition and enforcement laws to make them more uniform would be welcome to create uniformity, those changes likely would not make a practical difference. Scholars focus much of their attention on the systemic inadequacy ground for non-recognition, but courts rarely apply that ground, choosing instead to apply less politically sensitive grounds for non-recognition. ${ }^{273}$ In the Lago Agrio proceedings, the New York Recognition Act ended up not even playing a role in Chevron's eventual and successful tactic of a bench trial based on RICO. ${ }^{274}$

\section{THE Potential FOR SOlUtions In PUBlic INTERNATIONAL LAW}

Commentators also critique the existing public international law regime for providing insufficient forums to individuals for resolving their environmental claims. ${ }^{275}$ Many international tribunals like the International Court of Justice are available only to sovereign states as parties. $^{276}$ The interests of States and their people do not always

to join all potential defendants in one action).

272. Consistency goes hand-in-hand with judicial economy. See, e.g., FED. R. CIV. P. 19(a)(1)(B)(ii) (requiring the joinder of parties where an existing party is at risk of incurring "inconsistent obligations"); Parklane Hosiery Co., 439 U.S. at 330 (limiting offensive collateral estoppel "if the judgment relied upon as a basis for the estoppel is itself inconsistent with one or more previous judgments in favor of the defendant").

273. See Rhetoric of Recognition, supra note 4, at 235 (citing Thomas Kelly, Note, An Unwise and Unmanageable Anachronism: Why the Time Has Come to Eliminate Systemic Inadequacy as a Basis for Nonrecognition of Foreign Judgments, 42 GEO. J. INT'L L. 555, 565, 575 (2011); Carodine, supra note 9, at 1234-36).

274. Chevron sought only equitable relief, both on non-statutory grounds as well as under RICO. Chevron Corp. v. Donziger, 974 F. Supp. 2d 362, 555, 567 (S.D.N.Y. 2014). The Lago Agrio Plaintiffs attempted to rely upon the Ecuadoran judgments as part of a promissory estoppel defense against Chevron, but Judge Kaplan refused to consider them because they would not be entitled to recognition and enforcement under New York law. Id. at 608-17.

275. Peggy Rodgers Kalas, International Environmental Dispute Resolution and the Need for Access by Non-State Entities, 12 ColO. J. InT'L ENVTL. L. \& POL'Y 191, 242-43 (2001); see Giorgetti, supra note 5, at 794 (writing that "there are no international forums that have general jurisdiction over mass tort claims").

276. See id. at 207-08. 
coincide, so States may not bring claims on behalf of their people. ${ }^{277}$ Further, indigenous peoples like the plaintiffs in the Lago Agrio proceedings are not recognized as States, and their own countries often do not bring claims on their behalf because those countries are "unconcerned about the environmental needs and interests of their indigenous inhabitants.",278

Those tribunals that do allow participation by individuals suffer from several important limitations. For example, the United Nations Human Rights Committee can issue only non-binding opinions. ${ }^{279}$ In both the Human Rights Committee and the IACHR, individuals can bring claims only against sovereign states but not other private entities. ${ }^{280}$ The Lago Agrio plaintiffs initiated an action in the IACHR against Ecuador, but the Commission does not have jurisdiction over Chevron. ${ }^{281}$ In addition, those tribunals often have treaty-based restrictions on their subject matter jurisdiction. ${ }^{282}$ Even if the Lago Agrio plaintiffs had maintained their action against Ecuador, the IACHR can only grant relief for violations of human rights. ${ }^{283}$ The Lago Agrio plaintiffs secured a judgment based upon environmental torts, an area that has not reached the status in international law as a human right, even for indigenous peoples. ${ }^{284}$

Despite the limitations of the existing regimes, turning to public international law may nevertheless provide a solution involving a merger of public and private international law. ${ }^{285}$ For example, Robertson sees an important role for the Executive in negotiating bilateral, and even multilateral, treaties that would ensure court access. ${ }^{286}$ She suggests that developing countries in negotiations for BITs could insist on provisions for their citizens to have access to U.S. courts for tort claims arising from

277. Id. at 208 .

278. Bolívar, supra note 10, at 126-27.

279. Id. at $135-36$.

280. Kalas, supra note 275 , at 217-18.

281. Bolívar, supra note 10, at 139; Giorgetti, supra note 5, at 792; see Kalas, supra note 275, at 212-13 (writing that proceedings before the Permanent Court of Arbitration require that one of the parties must be a State, and that both parties must agree to submit the dispute).

282. Bolívar, supra note 10, at 139.

283. Id.

284. See Giorgetti, supra note 5, at 793; Kalas, supra note 275, at 215.

285. See, e.g., Kalas, supra note 275 , at 243 (proposing a multilateral treaty creating an International Environmental Court that could hear claims brought by individuals); see also Baker \& Parise, supra note 3, at 18-19 (writing that "international tort litigation raises considerations of foreign policy and public international law, which are properly the responsibility of the federal government."); Percival, supra note 5, at 584 (claiming that the "traditional disciplinary distinctions between domestic and international law, and between private and public law, continue to erode").

286. See Robertson, supra note 3, at 1129 (discussing restrictive litigation as a potential default rule subject to modification using treaties). 
the conduct of U.S. defendants, and that the FNC doctrine should not apply to those cases. ${ }^{287}$

Another potential for BITs is providing a means for alternative dispute resolution. While Chevron's initiation of arbitration multiplied the venues in which the stakeholders must contend, ${ }^{288}$ international arbitration also has the potential to provide a single forum for all stakeholders. Sheffer recognizes five major actors in the operation of BITs: the Home State, which is the capital exporting state like the United States; the Host State, which often has natural resources, such as Ecuador and other developing countries; investors, typically multinational corporations that engage in operations in the Host State; impacted nonState actors, such as citizens who reside near the corporate operations; and arbitration tribunals. ${ }^{289}$ Following a BIT, the Host State and investor typically enter into a concession agreement to conduct activities like mineral extraction and the construction of public utilities. ${ }^{290}$ An arbitration provision is a common feature of BITs between the United States and developing countries. As with the U.S.-Ecuador BIT, these provisions allow the investor to bypass the Host State's domestic courts and go to arbitration under specified rules. ${ }^{291}$ Current BITs focus on investor protection and the resolution of commercial disputes, but they have no provision for human rights and broader public interest considerations, nor do they allow for access by impacted non-State actors. ${ }^{292}$ This focus might actually undermine the Host State's ability to regulate environmental protection and prevent corporate abuses of human rights. ${ }^{293}$

Though the interests of developing countries and their citizens do not always align in the arena of commercial development, ${ }^{294}$ those States are nonetheless concerned with their citizens' access to a forum-especially because their injuries are often compensated with public funds. ${ }^{295}$ While multinational corporations are often portrayed as more powerful than the Host States because of their tremendous capital, developing countries are

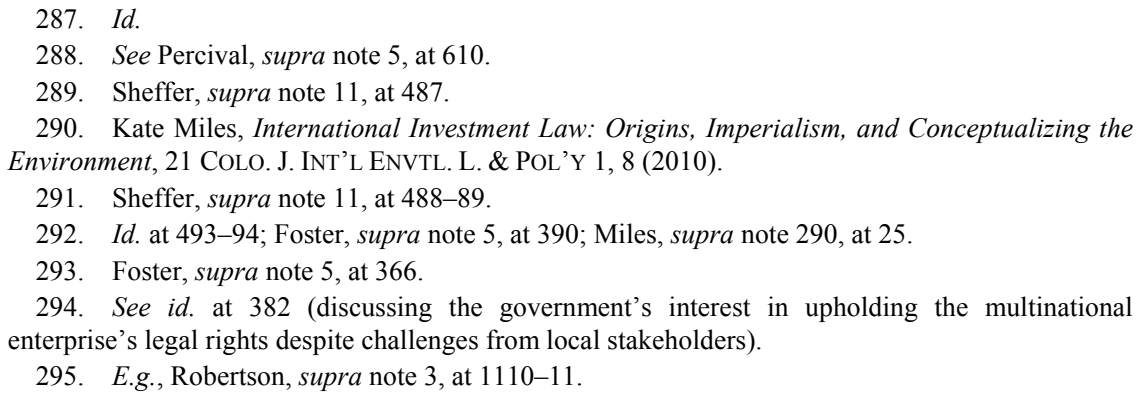


not without strength: specifically, Host States have sovereignty, and the accompanying right to grant concessions to develop natural resources. ${ }^{296}$ To entice investors to agree to arbitration, Host States could therefore condition government benefits on investors agreeing to arbitration that includes individuals, whether as amicus curiae or as a mechanism to uphold human rights obligations. ${ }^{297}$ Foster writes that a necessary condition for the Host States to demand broader arbitration participation is that the arbitral tribunals not have jurisdiction to award monetary or other relief against the Host State. ${ }^{298}$ He cites the Lago Agrio proceedings for some examples of the benefits of citizen participation in international arbitration: it allows the Host State to meet its human rights obligations - in particular for their indigenous peoples - and it minimizes the possibility of multiple proceedings. ${ }^{299}$

\section{ANALYSIS AND APPLICATION}

Although turning to BITs to open up U.S. courts or international arbitration tribunals to foreign plaintiffs has potential, this solution requires that the governments of the United States and of the Host State have "the political will" to open up participation, ${ }^{300}$ and assumes that corporations will continue to invest in the Host State when faced with the elimination of procedural obstacles to mass tort suits. A rhetorical analysis of the actions and texts from the Lago Agrio proceedings suggests that these stakeholders do not want full participation, however. Stakeholders continually reverted to the language of ecospeak, often reducing complex relationships by identifying the interests of an absent party with those of a participating party, thus framing issues in terms of us versus them. Indeed, this analysis shows that Ecuador as well as Texaco and then Chevron took advantage of the limitations of current fora to avoid exposing themselves to liability.

\section{A. Ecuador: Host State Avoids Liability by Controlling Proceedings}

Scholars have long documented how corporations take advantage of doctrines like FNC to avoid a U.S. trial, but the Ecuadoran government

\footnotetext{
296. See Foster, supra note 5, at 369-73 (discussing the various bargaining powers that developing countries have with multinational corporations).

297. Id. at 393, 399; Sheffer, supra note 11, at 506.

298. Foster, supra note 5, at 404.

299. Id. at 398, 404-07.

300. Id. at 369 .
} 
in Aguinda also showed an unwillingness to expose itself to U.S.-sized liability. ${ }^{301}$ Ecuador first took the position that it did not support a trial in the United States-Ecuadoran ambassador to the United States Edgar Teran wrote in a letter that the action was "an affront to Ecuador's national sovereignty," and that "Ecuador had a paramount interest in formulating its own environmental and industrial policies, and that Ecuador's courts were open to adjudicate such disputes." ${ }^{\text {,302 }}$ This initial stance is justified in light of the continuum: the government of Ecuador shared an interest in the dispute based on its sovereignty, but it had interests that differed from the other stakeholders like big business and the plaintiffs. ${ }^{303}$ If Ecuador would have maintained that position, then this stance suggests that it would be open to a solution through a BIT. Treaties are the result of sovereign negotiations, so having a hand in choosing the forum, either in the United States or arbitration, would reinforce Ecuador's say.

Instead, Ecuador changed its stance, not only coming out in support of the plaintiffs but even filing a motion to intervene. ${ }^{304}$ In an affidavit, Ecuador's attorney general contradicted its earlier stance by concluding that the intervention did not damage Ecuador's sovereignty. ${ }^{305}$ Instead, Ecuador "looks to protect the interests of the indigenous citizens of the Ecuadorian Amazon who were seriously affected by the environmental contamination attributed to the defendant company."306 By seeking to intervene, Ecuador explicitly identified its interests with the plaintiffs', thus creating a plaintiff and Ecuador versus Texaco opposition.

This stance was merely a frame, and in many ways a false frame, because it ignored the ways in which some interests of Ecuador and plaintiffs were adverse while some interests of Ecuador and Texaco were shared. ${ }^{307}$ For decades, PetroEcuador was part of the consortium and had a hand in operations, so the plaintiffs could potentially assert similar claims against Ecuador and PetroEcuador that they could against Texaco.

\footnotetext{
301. See supra notes 205-209 and accompanying text; Aguinda v. Texaco, Inc., 142 F. Supp. 2d 534 (S.D.N.Y. 2001), aff'd, 303 F.3d 470 (2d Cir. 2002).

302. Jota v. Texaco, Inc., 157 F.3d 153, 156 (2d Cir. 1998).

303. See Killingsworth \& Palmer, supra note 17, at 10-17 (discussing the human perspective on nature as a continuum on which governments neither fall to the scientific nor business side; rather, governments are dedicated to the perpetuation of a "social system," and nature becomes either an object to be studied or a resource to manage depending on the current political aim).

304. Jota, 157 F.3d at 158 .

305. Id

306. Id. (internal quotation marks omitted).

307. See KillingSWORTH \& PALMER, supra note 17, at 9 (characterizing ecospeak as a reversion to an "oversimplified dichotomy").
} 
Texaco would therefore have a claim for contribution from its consortium partner. The plaintiffs needed Ecuador to intervene to support their claim for equitable relief that would necessarily occur in sovereign Ecuadoran territory. The plaintiffs therefore gave Ecuador and PetroEcuador a judgment reduction agreement in the amount of contribution that Texaco might obtain. ${ }^{308}$ Plaintiffs and Ecuador thus recognized different stakes and had to form an alliance to overcome them to put on a joint front against Texaco.

Ecuador's relationship with Texaco is more complicated than simple opposition, however. No one disputes that petroleum operations in Lago Agrio have resulted in pollution. ${ }^{309}$ During the Aguinda proceedings, Texaco and Ecuador worked together to remediate that pollution. ${ }^{310}$ While scholars have criticized the level of remediation actually performed by Texaco, Texaco did at least contract with outside providers and engage in $\$ 40$ million worth of projects, while Ecuador itself performed no work - and has even continued to operate facilities and equipment that are dated and in disrepair. ${ }^{311}$ While this remediation occurred, Ecuador did not align its interests with the plaintiffs', who were not consulted during negotiation of the remediation agreements. ${ }^{312}$ Ecuador's attempt at consubstantiation with plaintiffs in its motion to intervene is therefore a retreat to the monolithic concept of the nationstate, a rhetorical construct that assumes a common space between government and people. ${ }^{313}$

This construct is not false-or, at least, it need not have been. Ecuador could have entered the fray against Texaco by waiving sovereign immunity, an act that would have opened it to a claim for contribution for its share of the consortium's operations or even indemnity based on the 1993 Memorandum of Understanding and subsequent remediation agreements. The absence of Ecuador in the Aguinda proceedings weighed heavily in the decision to grant, and then affirm, an FNC dismissal. Prior to reaching the elements of the FNC test, Judge Rakoff wrote "the Government of Ecuador, [] either directly or through the state-owned corporation PetroEcuador, regulated the

\footnotetext{
308. See discussion supra Section III.B.

309. See, e.g., Chevron Corp. v. Donziger, 974 F. Supp. 2d 362, 385 (S.D.N.Y. 2014) ("The Court assumes that there is pollution in the Orienté").

310. Kimerling, supra note 2, at 496-514.

311. Id. at 494-514.

312. Id. at $469,494$.

313. See Carpenter, supra note 17, at 208 (discussing the nation state as influential because it is an "imagined community" used to achieve stability and unity through a common sense of place and self).
} 
Consortium."314 He called attention to the fact that Ecuador was not a named party nor could Ecuador be sued as a third-party defendant "since it has now formally affirmed that it will not waive sovereign immunity."315 During the weighing of the private interest factors, his language in portraying the absence of Ecuador was quite strong:

[R]eference must again be made to the glaring facts that neither the Government of Ecuador nor PetroEcuador, the state-run oil company that owns the Consortium and had primary control of it through much of the relevant time period, are parties to the instant suits, whereas they could be joined in any similar suit brought in Ecuador. ${ }^{316}$

He also referenced the absence of Ecuador as a party in the public interest factors, characterizing preference given by the consortium to oil exploitation over environmental protection as a "conscious choice made by the Government of Ecuador" that could be adjudicated in Ecuador, "where (as noted) the Government of Ecuador can be joined as a party." 317 The Second Circuit affirmed, finding on the private interest factors that the "evidence of Texaco's defenses implicating the roles of PetroEcuador and the Republic" is located in Ecuador. ${ }^{318}$ The Court continued:

We also find significant that the Republic and PetroEcuador, neither of which are parties to the current suits, could be joined if the cases were resumed in Ecuador. ... We agree with the district court's observation that in the absence of the Ecuadorian Republic as a party, a U.S. court would be incapable of effectively ordering several aspects of the equitable relief sought in the complaints. ${ }^{3}$

The presence of Ecuador and PetroEcuador as parties may not have altered Judge Rakoff's decision to dismiss, but it would have made for a closer balancing of the factors, especially since the Second Circuit had already remanded the first FNC dismissal.

Their absence is more important for a rhetorical analysis of potential solutions to foreign plaintiffs' lack of an adequate forum: when given the possibility of a forum that included full participation of all stakeholders,

314. Aguinda v. Texaco, Inc., 142 F. Supp. 2d 534, 537 (S.D.N.Y. 2001), aff'd, 303 F.3d 470 (2d Cir. 2002).

315. Id

316. Id. at $550-51$.

317. Id. at 551 (parentheses in original).

318. Aguinda v. Texaco, Inc., 303 F.3d 470, 479 (2d Cir. 2002).

319. Id. 
Ecuador declined. $^{320}$ Instead, it sought to avoid liability by controlling the proceedings. By enacting the EMA, Ecuador could stay out of litigation while still providing plaintiffs a forum - a forum in which the bulk of the damages would flow back to Ecuador. ${ }^{321}$ By the time the Second Circuit affirmed dismissal, Texaco had completed its portion of the remediation, so Ecuador no longer needed to pretend to align its interests with Texaco. Ecuador therefore enacted the EMA with the participation of the plaintiffs' attorneys. ${ }^{322}$ Instead of being liable to plaintiffs, Ecuador would receive billions in damages from Chevron. Indeed, even individuals within the Ecuadoran government took advantage of the situation by accepting bribes from plaintiffs. ${ }^{323}$

The actions of Ecuador show the obstacles to negotiating a BIT that will allow for participation by all stakeholders in a forum that can provide a full remedy. One proposal is for foreign plaintiffs to get access to U.S. courts without the possibility of FNC dismissal. ${ }^{324}$ U.S. court access would obviate the need for laws like the EMA, thus eliminating one cause of fraud. And the BIT could be negotiated to provide for streamlined access to witnesses and documents, thus eliminating another problem for defendants and offering a guard against fraud. Ecuador has already declined to waive sovereign immunity, however, so why would it do so as part of a BIT? The U.S. State Department is unlikely to agree to open its courts without a waiver of sovereign immunity, thereby exposing its corporations to multi-billion-dollar litigation that may be attributable in part to the Host State. Without this waiver, proceedings in the United States would suffer from the same limitations as the Aguinda proceedings. If the United States were to insist on a waiver, the Host State might simply pull out of BIT negotiations, deciding that its potential exposure is too great and reasoning that corporations might choose to invest anyway.

The other option from a BIT is arbitration tribunals. In the ChevronEcuador arbitration, Ecuador portrayed its interests as separate from the plaintiffs", characterizing them as "third parties" and their claims as "third-party claims." "25 From a rhetorical standpoint, this framing sends

320. Aguinda, 142 F. Supp. 2d at 537.

321. E.g., Chevron Corp. v. Donziger, 768 F. Supp. 2d 581, 599, 621 (S.D.N.Y. 2011), rev'd sub nom. Chevron Corp. V. Naranjo, 667 F.3d 232 (2d Cir. 2012).

322. See discussion supra Part III.B.

323. Chevron Corp. v. Donziger, 974 F. Supp. 2d 362, 558 (S.D.N.Y. 2014) (Ecuadoran Judge Zambrano was bribed $\$ 500,000$ to rule in favor of Lago Agrio plaintiffs).

324. Robertson, supra note 3, at 1129.

325. First Partial Award on Track I, Chevron Corp. v. Republic of Ecuador, No. 2009-23, 27 (Perm. Ct. Arb. Sept. 17, 2013), http://www.italaw.com/sites/default/files/case-documents/italaw 
a mixed message. While welcome in its recognition of the complex interests and interrelationships in the environment, it also demonstrates Ecuador's awareness that the interests of many of its citizens are adverse to its own. ${ }^{326}$ Host States will allow for citizen participation in international arbitration only if that tribunal has no jurisdiction over the Host State. ${ }^{327}$ Given its actions in the Aguinda proceedings, and subsequent attempts to avoid liability by controlling proceedings through the EMA, there is no reason to think that Ecuador would waive immunity simply because the forum is an arbitral tribunal rather than a U.S. court.

\section{B. ChevronTexaco: Corporations Take Advantage of Ambiguity to Identify Interests of Absent Party with a Present Party}

Nor would a multinational corporation like Chevron favor opening access to foreign plaintiffs. A rhetorical analysis reveals that Texaco in Aguinda and now Chevron in arbitration have taken advantage of the limited access to the particular forum by identifying the absent party's interests with another party. In a twist on the result of the public debate over the proposed biomass facility in Valdosta, ChevronTexaco has prevailed by construing the absent party in narrow and exclusionary ways. That outcome should not be surprising, however, because Ecuador's arguments assume unproblematic and uncomplicated identities while ChevronTexaco has taken advantage of ambiguity to foster identifications that are more persuasive. ${ }^{328}$ In both sets of proceedings, the court has adopted ChevronTexaco's framing of interests and rejected Ecuador's attempts to show a multiplicity of interests. ${ }^{329}$ Because of its success, Chevron is likely to lobby against greater access.

In Aguinda, Texaco identified its interests with Ecuador and PetroEcuador, focusing upon their shared responsibilities in operating the consortium and thus creating additional defendants. ${ }^{330}$ The Second Circuit recognized an inherent similarity in all three grounds upon which Texaco moved to dismiss: "the close participation of the Ecuadoran 
government in the activities for which Texaco was sought to be held liable." 331 The evidence submitted by Texaco showed that PetroEcuador not only had an ownership stake, but also operational involvement, including becoming the "sole operator." "332 The trial court adopted Texaco's view that Ecuador and PetroEcuador "regulated the Consortium from the outset" and "had primary control of it through much of the relevant time period." 333 The Second Circuit likewise recognized that Texaco's defense was predicated upon "implicating the roles of PetroEcuador and the Republic." 334 As described in the previous subsection, the three binary relationships among the plaintiffs, Ecuador, and Texaco involved both overlapping as well as separate interests. ${ }^{335}$ While Ecuador framed its interests as aligning with the plaintiffs', Texaco framed Ecuador as opposed to the plaintiffs, and thus as another defendant. ${ }^{336}$ In light of Ecuador's refusal to waive sovereign immunity and join as a party, the courts accepted Texaco's narrative. ${ }^{337}$

Chevron has carried this strategy forward in the arbitration, except that plaintiffs are the absent party, so Chevron has identified the interests of the plaintiffs as aligned with those of Ecuador. The panel devotes considerable space to each party's arguments in the First Partial Award on Track I. ${ }^{338}$ A textual analysis reveals that Chevron's arguments are rhetorically effective because they take a nuanced approach to creating identification, whereas Ecuador argues for division based upon a more simplistic and artificial division of interests. Chevron conceded that the 1995 settlement agreement with Ecuador did not preclude environmental claims made by individuals for personal harm. ${ }^{339}$ The Lago Agrio plaintiffs did not prevail on personal injury claims, however, but on claims based solely on the EMA, which grants individuals standing to sue for environmental harms to the state. ${ }^{340}$ Before passage of the EMA in 1999, only the Republic of Ecuador and not individual Ecuadorans would have had standing to assert these claims. ${ }^{341}$ In this way, the

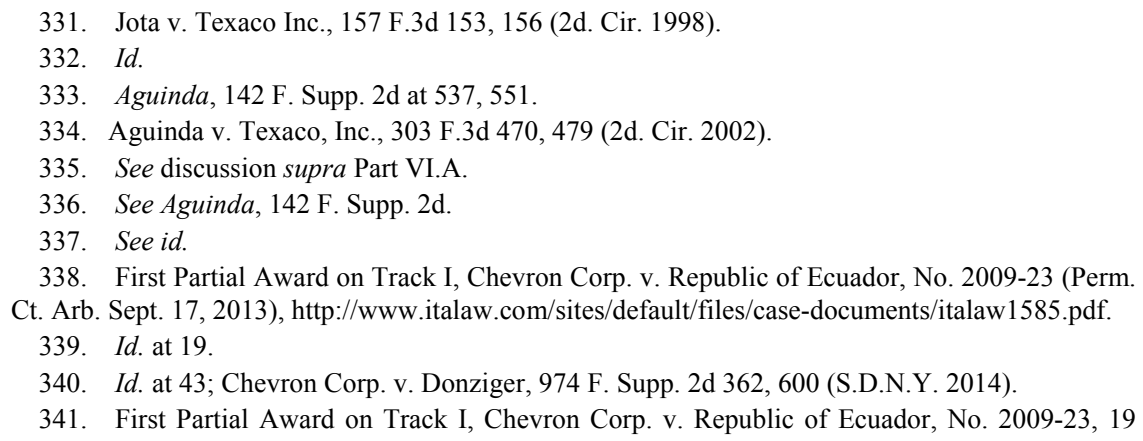


plaintiffs' standing is based upon a collective right, a right shared by Ecuador, rather than the individual claims that were asserted in Aguinda. $^{342}$ Because Ecuador had released Chevron's predecessor Texaco from liability before 1999, Ecuador could not revive that right by transferring standing to its citizens. ${ }^{343}$ The essence of Ecuador's response is that collective rights did not exist in 1995 and were only manifested for the first time in the 1999 EMA, so it could not have settled individual claims in $1995 .{ }^{344}$ Most telling is Ecuador's attempt to distance itself from the Lago Agrio plaintiffs, portraying them as "third parties" so that Ecuador's releasing Texaco from liability in the remediation agreements would not apply to the plaintiffs. ${ }^{345}$ The tribunal accepted part of Ecuador's argument, agreeing that individuals did not have the ability to assert an individual claim in 1995, but the tribunal concluded that Ecuador did have that right in 1995, which it exercised by releasing Texaco and its successors from liability. ${ }^{346}$ Rather than create a collective right, the 1999 EMA merely attempted to revive a right that had already been extinguished. ${ }^{347}$

Though for different reasons than Ecuador, Chevron would likewise oppose a BIT, whether it opened up U.S. courts or provided for international arbitration. In Aguinda, Texaco won dismissal in part by portraying Ecuador as a co-defendant that could not be made a party. ${ }^{348}$ Even if the BIT contained a waiver of sovereign immunity, Chevron would therefore prefer to keep Host States like Ecuador out of U.S. proceedings so it can maintain this advantage in framing identities. In the arbitration, Chevron has been able to prevail thus far by identifying the plaintiffs with Ecuador, so it does not want plaintiffs, even as amici, to have the ability to offer their own arguments to the tribunal. After all, these plaintiffs have at least attempted to bring separate claims against Ecuador in the IACHR. If arbitration had been available to the individual plaintiffs from the outset, it is likely that the plaintiffs would have asserted only claims for injury to themselves and their personal

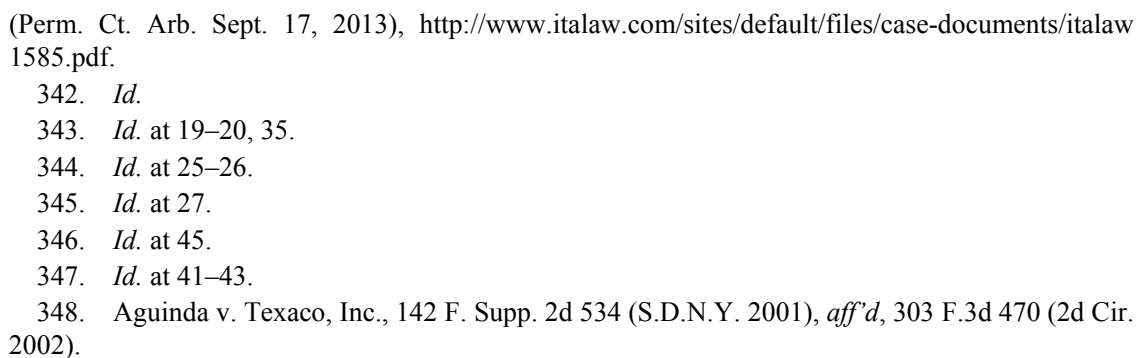


property, and not for environmental harm, ${ }^{349}$ undercutting the entire basis for Chevron's argument.

Robertson describes how Congress is subject to interest-group lobbying, so that domestic legislation that opened court access would be opposed by large oil and gas entities like Chevron. ${ }^{350}$ A BIT requires executive negotiation and Congressional ratification, so Chevron could certainly apply the same pressure to Congress and the Department of State to keep individual access provisions out of BITs. Plus, the BIT only opens up the potential for investment; the Host State and corporations must follow through with concession agreements. ${ }^{351}$ Investors would weigh the increased exposure in deciding whether or not to invest. Given the Host State's interests in economic development, an interest that is sometimes adverse to its own citizens, the Host State might even agree to concession agreement workarounds to open forums.

\section{CONCLUSION}

Ecospeak is a retreat to entrenched positions, a resort to ready-made labels that prevent finding solutions based upon the interests of all stakeholders. The purpose of rhetorical analysis is to study the environmental discourse and push past the ecospeak for points of identification that might lead to cooperation. ${ }^{352}$ Accordingly, while this analysis has revealed ways in which Host States and investor corporations have taken advantage of the lack of access to a forum by foreign plaintiffs, it has also shown ways in which all three sets of stakeholders have - at various points - worked together. From these points of identification might emerge the seeds of a solution.

For example, all sides agreed on the need for environmental remediation, either through the direct negotiation of Ecuador and Texaco for the remediation agreements, or via the environmental damage awards made possible by the EMA. ${ }^{353}$ Although individual plaintiffs might be precluded from bringing some claims for environmental harms, nothing in the language of current BITs precludes the Host State from bringing those claims. Indeed, the Chevron-Ecuador BIT allows either the investor or Ecuador to initiate arbitration, and that arbitration could

349. See Foster, supra note 5, at 398 (opining that the Lago Agrio proceedings would have been better if they could have been brought from the outset in a neutral forum).

350. Robertson, supra note 3, at 1123-24.

351. Miles, supra note 290, at 8 .

352. KillingswORTH \& PALMER, supra note 17, at 9-10.

353. See discussion supra Parts III.A-B. 
extend to the tort effects of commercial activities. ${ }^{354}$ In this particular case, Ecuador settled separately and cheaply with Texaco, but other nations might take advantage of international arbitration in the future. ${ }^{355}$

While current BITs might expedite the resolution of general environmental harms, they do nothing to open up access for individual claims. Again, we can look at points of identification to seek a solution. Host States and investing corporations do not resist opening access to individual plaintiffs because their interests are completely opposed; after all, the continuum of interests shows that there are points where interests intersect. Rather, Host States and corporations want to avoid exposure to U.S.-sized damages, both actual and punitive. ${ }^{356}$ In Aguinda, Texaco sensibly did not want to remain in a forum where it would have to pay damages for a class that included 30,000 Ecuadorans, nor would Ecuador want to assume even a fraction of those damages. ${ }^{357}$

FNC has been a popular device because developing countries often have substantially lower damage awards than are common in the United States. ${ }^{358}$ While these awards may be modest by U.S. standards, they can represent several times the average family's annual income, and therefore have a real impact on citizens of that developing country. ${ }^{359}$ BITs have the potential to account for these awards because the United States and Host State could create a provision that allows for access to arbitration for individuals, but keys damages to average incomes in the Host State or to reflect some measure like a multiplier of Host State incomes. This approach merges solutions proposed by scholars who see a role for BITs and international arbitral tribunals, with those who call for a return to choice of law principles that draw on Host State laws. ${ }^{360}$ With a recovery thus limited, investors may be more willing to allow

354. U.S.-Ecuador BIT, supra note 5, at art. VI(3)(a).

355. Another option is to head off environmental problems before they arise. For example, Sheffer suggests that BITs could obligate investors to engage in environmental impact assessments to evaluate the "anticipated impact on the local community's land, natural resources, air quality, water resources, and the like." Sheffer, supra note 11, at 514. She also recommends that these assessments be public and allow for a period of public comment. Id. at 516 .

356. See, e.g., Robertson, supra note 3, at 1087-88; Rhetoric of Recognition, supra note 4, at 236.

357. Aguinda v. Texaco, Inc., 303 F.3d 470 (2d Cir. 2002).

358. See Phantom Torts, supra note 13, at 298-99.

359. Id. at 306 (writing that $\$ 5,800$ pursuant to a $\mathrm{DBCP}$ exposure settlement program "represents five times the average annual per capita income in Nicaragua.").

360. Compare Foster, supra note 5, with Baker \& Parise, supra note 3, at 18 (noting that "[w]hatever justification there may be for allowing [interstate forum shopping] to prevail in interstate litigation, those considerations cannot justify state law governing international tort litigation.”). 
participation by individuals in arbitration, even if the Host State is immune from claims.

I characterized this proposal as only the seeds of a solution because it is not perfect. For example, from an efficiency perspective, it may not sufficiently deter tortious acts because the U.S. multinational measures profits by U.S. standards but damages by the standards of developing countries. ${ }^{361}$ However, as this environmental rhetoric analysis has shown, none of the other solutions are perfect either-and they may not even be feasible in light of the positions taken by stakeholders in the Lago Agrio proceedings. By taking account of points of identification among stakeholders, however, environmental rhetoric offers another perspective for scholars to consider as they debate how best to provide access to justice for foreign individuals alleging environmental torts.

361. E.g., Sheffer, supra note 11, at 520 (writing that the financial compensation from arbitration awards "would have to outweigh the benefits the corporation" receives from the violation of human rights to be an effective deterrent). 